\title{
Human Resource Flexibility as a Mediating Variable Between High Performance Work Systems and Performance
}

\author{
Inmaculada Beltrán-Martín* \\ Vicente Roca-Puig \\ Ana Escrig-Tena \\ Juan Carlos Bou-Llusar \\ Departamento Administracion de Empresas y Marketing, Facultad Ciencias Juridicas y \\ Economicas, Universitat Jaume I, Castellon (12071)-Spain
}

\begin{abstract}
Much of the human resource management literature has demonstrated the impact of high performance work systems (HPWS) on organizational performance. A new generation of studies is emerging in this literature that recommends the inclusion of mediating variables between HPWS and organizational performance. The increasing rate of dynamism in competitive environments suggests that measures of employee adaptability should be included as a mechanism that may explain the relevance of HPWS to firm competitiveness. On a sample of 226 Spanish firms, the study's results confirm that HPWS influences performance through its impact on the firm's human resource (HR) flexibility.
\end{abstract}

Keywords: human resource flexibility; high performance work systems; mediating effects; organizational performance; resource-based view

Over the past decades, several empirical studies have suggested that high performance work systems (HPWS) contribute to facilitating growth of organizations and improving

*Corresponding author: Tel.: +34-96472854; fax: +34-964728629

E-mail address: ibeltran@emp.uji.es

Journal of Management, Vol. XX No. X, Month XXXX xx-xx

DOI: $10.1177 / 0149206308318616$

(C) 2008 Southern Management Association. All rights reserved. 
performance (e.g., Arthur, 1992, 1994; Delaney \& Huselid, 1996; Huselid, 1995). Most of these studies draw from the resource-based view (RBV) to formulate and empirically demonstrate the relationship between HPWS and organizational performance (e.g., Becker \& Huselid, 1998; Huselid, 1995; Koch \& McGrath, 1996). However, some of the literature suggests that a better understanding of how HPWS enhance organizational effectiveness can be achieved by assuming that before it is evidenced in final results, HPWS influence other intermediate organizational outcomes, mostly related to employee responses and performance at work (Huselid \& Becker, 2000). Recently, a number of studies have made initial attempts to examine the processes that explain the influence of HPWS on firm performance (e.g., Moynihan, Gardner, Park, \& Wright, 2001; Ramsay, Scholarios, \& Harley, 2000), but to date there is a lack of unequivocal evidence about which variables mediate the relationship between HPWS and performance and to what extent they do so.

In this vein, contradictions have emerged regarding the actual relevance of a set of employee outcomes (e.g., employee skills, motivation, or commitment) as intermediate mechanisms. Some existing studies focusing on specific HPWS practices conclude that the indirect effect of HPWS on performance through employee outcomes depends on the HPWS practice that is taken into account (e.g., Fey, Bjorkman, \& Pavlovskaya, 2000; Paré \& Tremblay, 2007; Paul \& Anantharaman, 2003). Other scholars analyze HPWS as a whole and find that although some of these employee outcomes mediate the influence of HPWS on performance, the mediation effect is partial (e.g., Katou \& Budhwar, 2006; Park, Mitsuhashi, Fey, \& Bjorkman, 2003; Sun, Aryee, \& Law, 2007), which indicates that researchers should consider other potential mediator variables when explaining the intermediate processes. Finally, studies such as Moynihan et al. (2001) and Ramsay et al. (2000) showed weak and even nonsignificant effects of the mediator variables in their models. For example, Ramsay et al.'s (2000) discussion of their work highlighted that "the widely held assumption that positive performance outcomes from HPWS flow via positive employee outcomes has been shown to be highly questionable" (p. 521). In sum, prior evidence indicates that there are still some omitted variables in the HPWS-performance linkage that reduce the explanatory information of these models.

Recent theoretical advances in the HPWS field suggest that the debate should be taken further by including additional intermediate variables that can improve our understanding of the processes through which HPWS influence firm outcomes (e.g., Boxall \& Purcell, 2000). Specifically, the application of the RBV in the HPWS literature is placing growing emphasis on organizational flexibility and firm growth (Boxall \& Purcell, 2000). Colbert (2004) argued that limiting the discussion to adaptive concepts such as employee organizational commitment, which contribute to implementing an a priori defined strategy, limits the power of the RBV as originally articulated by Penrose (1959). The relevance of HPWS should not only focus on the attainment of favorable returns in the current context but also on preparing firms for the challenges of the new context (Evans \& Genadry, 1999). Recent attention to the increasing dynamism of competitive environments and the emergence of new principles to manage firms in these contexts points to human resource (HR) flexibility as a potential mediator of the relationship between HPWS and organizational outcomes (Bhattacharya, Gibson, \& Doty, 2005; Cappelli \& Newmark, 2004; Dyer \& Shafer, 2002; van den Beukel \& Molleman, 1998). 
Figure 1

Theoretical Models

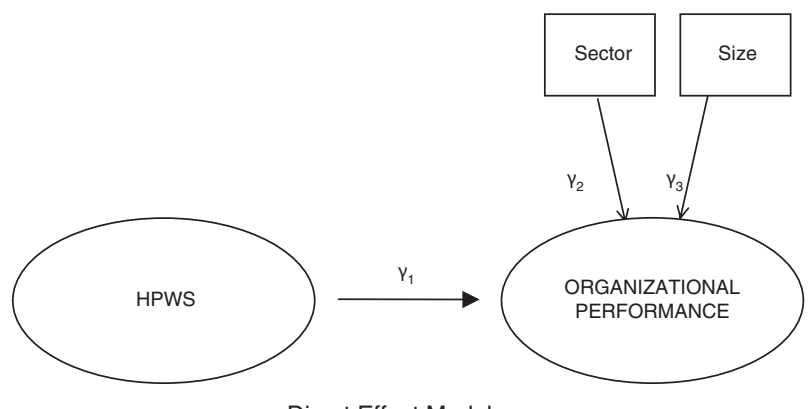

Direct Effect Model

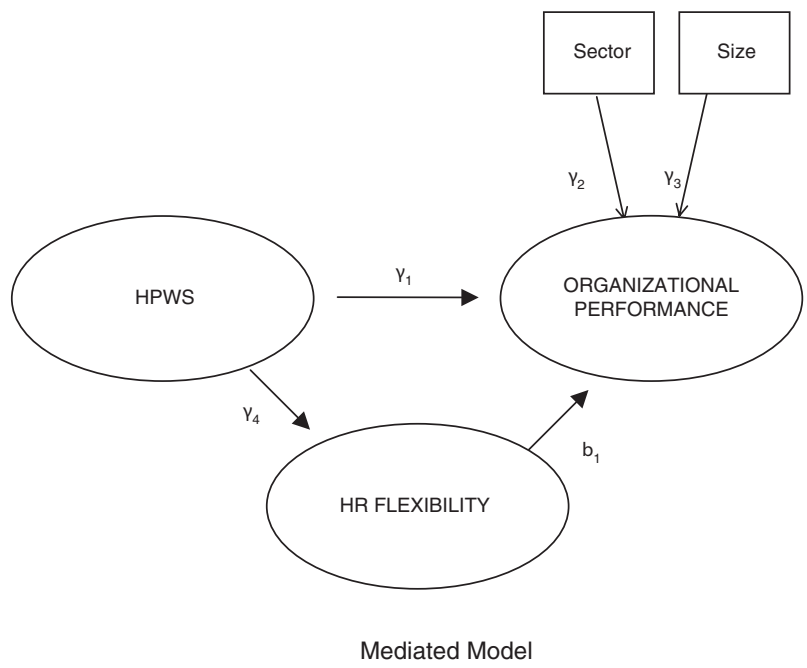

Note: HPWS = high performance work systems; HR = human resource.

The purpose of our study is to empirically test whether HR flexibility acts as a mediating variable in the HPWS-firm performance linkage (Figure 1). Although various scholars highlight the relevance of HR flexibility as a potential mediator (e.g., Bhattacharya et al., 2005; Wright \& Snell, 1998), this study is arguably among the first to examine the potential intervening role of this variable in the relationship between HPWS and organizational performance. Our research sets out to complement previous research work that explores the mechanisms between HPWS and performance by considering a more proactive component of employee performance at work that goes beyond traditional job-related variables such as 
employee commitment or satisfaction and that is in accordance with the most recent RBV trends (Boxall \& Purcell, 2000).

The article is organized in five sections. The first section offers an overview of HPWS and its contribution to firm performance. The second section presents the definition of HR flexibility from the resource-based view and its consideration as a mediating mechanism in the HPWS-performance linkage. In the third section, we present the empirical research carried out and the methodology. The fourth section provides an overview of the main results, and the fifth section summarizes the conclusions, implications, and future lines of research stemming from this study.

\section{High Performance Work Systems}

The term high performance work systems refers to a human resource management approach that tries to elicit employee commitment to and involvement with the organizational goals so that people's behavior is self-regulated rather than controlled by sanctions and pressures (Walton, 1985; Wood \& Albanese, 1995). This commitment-oriented model has been central in the human resource management (HRM) field, and many related terms have emerged, such as high commitment management (e.g., Arthur, 1994; Gallie, Felstead, \& Green, 2001; Whitener, 2001), high involvement management (e.g., Edwards \& Wright, 2001; Guthrie, 2001), or progressive human resource management (e.g., Cappelli \& Newmark, 2001; Ichniowski, 1990), all of which have been regarded as synonyms.

HPWS aim to increase productivity and effectiveness and rely on conditions that help employees to identify with the firm's goals and to work hard to accomplish those goals (Whitener, 2001). With this purpose, the adoption of HPWS entails the use of certain HRM practices, although no consensus has yet been reached on what these practices are (Becker \& Gerhart, 1996; Dyer \& Reeves, 1995; Guest, 1997; Wright \& Gardner, 2003). In our research we consider that HPWS are made up of four dimensions, namely, comprehensive staffing, extensive training, developmental performance appraisal, and equitable reward systems. In line with some scholars (e.g., Snell \& Dean, 1992; Wright, Garnder, \& Moynihan, 2003; Wright, McCormick, Sherman, \& McMahan, 1999; Youndt, Snell, Dean, \& Lepak, 1996), we consider these dimensions to represent the major areas of HPWS that appear in almost all the empirical research in this field.

HPWS comprise practices aimed at enhancing the firm's human capital, under the premise that employee potential is not fully utilized and can be enhanced through the appropriate means. According to Delery and Doty (1996), a higher level of human capital can be attained by focusing on either the selection processes that determine the characteristics of the workforce or on developmental actions covering current employees, which thus introduces the first two dimensions of HWPS, respectively.

First, human capital-enhancing efforts can be oriented toward guaranteeing an appropriate competence pool among the employees hired. In this vein, comprehensive staffing procedures are a critical element to determine the nature of the organization's future workforce (Delaney \& Huselid, 1996; Huselid, 1995; Whitener, 2001; Youndt et al., 1996). HPWS place special emphasis on finding the right person for each position by, for instance, 
considering a high number of candidates for each vacancy (Huselid, 1995; Whitener, 2001) or using extensive and detailed staffing procedures (Snell \& Dean, 1992).

Second, organizations can improve their human capital by providing developmental activities after selection. Several studies in the HPWS literature have highlighted the need for extensive training programs either in terms of the number of hours provided or the percentage of employees covered by the training programs (Delaney \& Huselid, 1996; MacDuffie, 1995; Youndt et al., 1996).

Third, another main feature of HPWS is that they attempt to eliminate the worst aspects of routinized work and to provide intrinsically satisfying tasks (Wood \& Albanese, 1995). From an HPWS philosophy, the organization tries to utilize human resources to the fullest by providing high-quality, challenging jobs (Guest, 1987). When work is enriched as in an HPWS context, performance appraisal takes on an important developmental role. The discretion encouraged in employees is often accompanied by a managerial emphasis on devoting more time to providing feedback, discussing problems, and identifying areas for employee performance improvement (Snell \& Dean, 1992).

Fourth, because employees need to be motivated to contribute effectively to organizational success, HPWS also provide a rewards structure consisting of monetary and nonmonetary rewards that employees perceive as equitable (Applebaum, Bailey, Berg, \& Kalleberg, 2000; Bailey, 1993; Takeuchi, Marinova, Lepack, \& Moon, 2004). Research in social psychology has demonstrated that employees' perceptions of equity affect their decisions to join, remain, and produce for a firm (Snell \& Dean, 1992). In this regard, HPWS promulgate reward equity that leads to employees' perception of a match between their own inputs and outcomes and those of relevant others (Lam, Schaubroeck, \& Aryee, 2002; Paterson, Green, \& Cary, 2002). These relevant others may refer to other companies, that is, the firm offers similar rewards to other companies for the same job position (i.e., external equity), or to other employees within the organization, for example, by implementing merit pay schemes that reward employees in proportion to their contributions or by avoiding wide variations in salaries within the same unit (i.e., internal equity) (Campbell, Campbell, \& Chia, 1998).

In addition, the HPWS literature emphasizes the need to adopt coherent systems of practices (Arthur, 1994; Delery \& Doty, 1996) to capture the complementarities among the HPWS components, under the premise that an HPWS practice may be more effective in stimulating the desired employee outcomes when the firm implements it in concert with other HPWS practices (Ichniowski, Shaw, \& Prennushi, 1997). The empirical evidence shows that many HPWS practices are usually found together (i.e., there is an internal fit among them) because they are driven from a common philosophy (Gallie et al., 2001; Vandenberg, Richardson, \& Eastman, 1999). In terms of the conceptualization of HPWS presented in this study and following the suggestions by Wood and Albanese (1995), we assume that there is an underlying approach to the management of training, staffing, appraisal, and rewards practices that explains the association between them.

The RBV of the firm (Amit \& Schoemaker, 1993; Barney, 1991; Wernerfelt, 1984) argues that HPWS can lead to competitive advantages by developing a unique and valuable human capital pool (Delery, 1998). Studies such as Wright, McMahan, and McWilliams (1994) or Boxall and Purcell (2000) found that HPWS contribute to building a human capital pool and to stimulating certain valuable human behaviors in the firm that are at the same time rare and 
difficult to imitate. Many studies have demonstrated the strategic relevance of HPWS for the firm in terms of HPWS impact on organizational performance (Arthur, 1992, 1994; Delaney \& Huselid, 1996; Huselid, 1995; Huselid, Jackson, \& Schuler, 1997). In addition, some of these studies highlight the effect of integrated HPWS on organizational results due to added synergies gained from the conglomeration of practices (Delery \& Doty, 1996; MacDuffie \& Kochan, 1995; Park et al., 2003). Drawing from these studies, we formulate the following hypothesis:

Hypothesis 1: HPWS will have a positive effect on organizational performance.

\section{Human Resource Flexibility}

Organizations now operate in environments with unprecedented and unpredictable events resulting from several factors, such as technological advances or market globalization (Hitt, Keats, \& Demarie, 1998; Shafer, Dyer, Kitty, Amos, \& Ericksen, 2001). These circumstances have forced managers to make paradigm shifts in guiding their organizations, and new principles have emerged for managing firms in these environments where time frames for strategic decisions are shorter. The heightened demands on organizations have subsequently called for a corresponding staff of flexible and capable individuals (van den Beukel \& Molleman, 1998). In modern companies, proficiency in the performance of a set of assigned tasks is not enough to guarantee competitive advantages, and aspects related to employee flexibility are included in the new job performance standards (Hesketh \& Neal, 1999). In this section we first present a definition of HR flexibility proposed from the RBV perspective. Following this, we discuss the relevance that HR flexibility may have in the effect of HPWS on performance.

\section{HR Flexibility From the RBV}

As discussed earlier, the RBV of the firm is a valid framework in the HRM field (Wright et al., 1994). Moreover, it also provides an interesting theoretical basis on which to advance knowledge about HR flexibility (Bhattacharya et al., 2005; Chadwick \& Cappelli, 1999; Dyer \& Shafer, 1999; Lepak, Takeuchi, \& Snell, 2003; Wright \& Snell, 1998). From this theoretical point of view, the definition of HR flexibility has an internal orientation because HR flexibility refers to the extent to which employees possess skills and behavioral repertoires that can provide a firm with options to pursue strategic alternatives (Wright \& Snell, 1998). Employees like these, mobilized through the appropriate human resource practices, constitute a source of competitive advantages. Consequently, researchers should make greater efforts to disentangle the meaning and components of HR flexibility.

According to Wright and Snell (1998), one of the main features of a flexible workforce is employees' ability to accomplish a large number of diverse tasks. This idea corresponds to the notion of functional flexibility, which implies that employees are able to work on different tasks and under diverse circumstances and that the costs and time needed to mobilize employees into new duties or jobs are low (van den Berg \& van der Velde, 2005). Therefore, functional flexibility is similar to workforce versatility or polyvalence, which facilitates employee movements between jobs or the assumption of responsibility for multiple tasks from other jobs (Cordery, 1989; Riley \& Lockwood, 1997). 
Moreover, employees are flexible when they are able to learn quickly to perform new tasks (Bhattacharya et al., 2005; Wright \& Snell, 1998), which corresponds to the idea of skill malleability (Maurer, Wrenn, Pierce, Tross, \& Collins, 2003). Rather than focusing on the current breadth of competences, skill malleability refers to how easily and quickly employees assimilate new skills and abilities. In this sense, employees show skill malleability when they train and retrain as necessary, anticipate future skill requirements, or demonstrate enthusiasm for learning new approaches to perform their jobs (Arulampalam \& Booth, 1998; Dyer \& Ericksen, 2005; Pulakos, Arad, Donovan, \& Plondon, 2000).

Finally, flexible human resources are characterized by exhibiting behavior flexibility, that is, by showing a variety of behavioral repertoires in different circumstances (Bhattacharya et al., 2005). According to Wright and Snell (1998), employee behaviors are the scripts or sequences that employees adopt in their jobs. If an employee who has applied a particular script in repetitive work situations selects the same script to deal with a novel situation, his or her behaviors are considered rigid. In contrast, if employees look for new sequences of actions with which to perform their daily activities or to face new circumstances, their behaviors are flexible. Thus, this concept involves a greater tolerance for nonroutine behavior, according to which employees adapt their responses to new circumstances, based on improvisation and not on fixed patterns of action (Bhattacharya et al., 2005; Dyer \& Ericksen, 2005).

In sum, for the purposes of this study we consider three components in the definition of HR flexibility: functional flexibility, skill malleability, and behavior flexibility. This conceptualization resembles previous definitions provided from the RBV perspective (e.g., Bhattacharya et al., 2005).

In addition, a review of this literature provides several theoretical arguments that sustain the interdependencies between these dimensions. For instance, some authors hold that employees manifesting functional flexibility possess a wide repertoire of competences or a set of general abilities such as leadership or problem-solving skills that encourage them to extend their current pool of skills, that is, to show higher skill malleability (Wright \& Snell, 1998). Moreover, according to Simon (1993), continuous learning processes associated with employee skill malleability demand the adoption of new cultural values and structural mechanisms, which eventually change the viewpoint and the role of the individual in the firm and thus his or her willingness to show adaptable behaviors (Senge, 1990, 1993). Therefore, the definition of HR flexibility in our study takes into account the interdependencies among the dimensions of flexibility.

\section{HR Flexibility as a Mediating Variable}

Although the notion that flexible employees have become a competitive asset in modern organizations is widespread (Lawler, 1994), so far this claim has not been fully supported by empirical evidence. Studies on the influence of HR flexibility on organizational performance and on the relevance of HPWS to fostering HR flexibility provide a basis for the consideration of HR flexibility as a mediating variable in the HPWS-performance linkage.

HR flexibility-performance relationship. Several studies have demonstrated that employee functional flexibility, as one of the main components of HR flexibility, significantly affects firm performance. Studies within the framework of human capital theory argue 
that the pool of skills and abilities that underlies employees' functional flexibility determines their capacity to be responsible for several activities in the organization (Rönnmar, 2004). Employees with a broad knowledge base contribute to the organization's competitive advantage as this base generates greater capabilities to develop more efficient means of accomplishing task requirements (Boxall, 1999; Wright et al., 1994). Some scholars assume that higher functional flexibility leads to more satisfied and motivated employees and thus to higher labor productivity (Cordery, Sevastos, Mueller, \& Parker, 1993) and lower employee turnover (Kelliher \& Riley, 2003). Also, employee polyvalence reduces the number of line managers, thus diminishing administrative levels and associated costs (Valverde, Tregaskis, \& Brewster, 2000). Furthermore, employees who show functional flexibility maintain profitable relationships with customers, contributing to satisfying their needs and enhancing their satisfaction (Youndt \& Snell, 2004).

In addition, HR flexibility may be relevant in the adoption of innovative solutions in the firm because skill malleability implies that employees are able to respond in better ways to stimuli that have appeared previously. Furthermore, when employees continuously improve their pool of knowledge, their performance variability at work reduces over time, thereby increasing productivity (Lado \& Wilson, 1994). Similarly, the behavior flexibility dimension of HR flexibility encourages organization members to improvise and think of new ideas, question and reflect on their actions, and make sense of and generate new understandings from those actions. For example, it permits organization members to reduce production and service delivery costs and develop new process innovations that eliminate costly steps or reduce inputs (Youndt \& Snell, 2004). Some empirical studies have demonstrated the impact of this type of employee on job performance (Crant, 1995), job satisfaction (Seibert, Crant, \& Kraimer, 1999), productivity, customer service and commitment (Kirkman \& Rosen, 1999), and financial performance measures (Bhattacharya et al., 2005).

HPWS-HR flexibility relationship. The benefits that HR flexibility provides for the firm's performance have encouraged researchers to analyze the mechanisms through which the firm can promote the flexibility of its workforce. In this sense, many authors consider human resource activities, and in particular HPWS, to be an appropriate instrument to increase HR flexibility levels (Dyer \& Shafer, 2002; Sparrow, 1998).

HPWS influence HR flexibility through human capital-enhancing activities, mainly related to training and staffing activities, which are oriented toward the promotion of a climate of personal growth in the firm, enabling employees to prepare for whatever the future might bring in terms of abilities or behaviors needed in the workplace (Shafer et al., 2001). Due to the rapid process of knowledge obsolescence in current environments, the importance of being "ahead on the learning curve" is crucial in creating flexible employees (Dyer \& Shafer, 2002). Extensive developmental activities in the HPWS are likely to favor the abilities needed to perform a variety of tasks effectively, namely, to promote functional flexibility (Friedrich, Kabst, Weber, \& Rodehuth, 1998; van Dam \& Thierry, 2000). In addition, the focus of HPWS on the workforce's development provides a firm with a skilled workforce capable of ongoing learning (Batt, 2002; Youndt \& Snell, 2004). Thus, these developmental efforts on the part of the organization are also beneficial in promoting the workforce's skill malleability because employees are keen to increase their current pool of skills and abilities 
when they possess a valid educational basis because proficiency in certain areas gives them the confidence to master and apply new skills (Wright \& Snell, 1998). The firm's efforts to broaden the workforce's skills and competences also allow employees to conceive alternative methods of carrying out their jobs, thus fostering behavior flexibility (Frese, Kring, Soose, \& Zempel, 1996; Parker \& Axtell, 2000).

The developmental appraisal component of HPWS encourages employee flexibility for several reasons. On one hand, appraisal activities constitute an organizational communication tool that helps the firm to shape the psychological contract, that is, to clarify the set of reciprocal expectations between the employee and the organization (Guest \& Conway, 2002). According to the psychological contract perspective, the use of developmental performance appraisals generates a more positive view of the exchange in the sense that the contract has been met and high levels of trust exist between the employee and the employer (Guest \& Conway, 2002). Employees who perceive they are being treated fairly in the organization are more willing to adjust to the kind of adversities that can appear in the workplace, therefore becoming more flexible (Cobb, Folger, \& Wooten, 1995; Moorman, 1991). In this regard, Cavanaugh and Noe (1999) found that employee participation in appraisal activities gives employees a greater sense of control over their professional careers, which contributes to fostering their willingness to participate in the firm's change processes through skill malleability or behavior flexibility.

On the other hand, the use of developmental appraisals comprises certain elements of employees' involvement, by allowing employees to participate in the establishment of performance standards or by discussing performance achievements with them, all of which contribute to extending the role of employees in the firm. Employees with extended roles in the firm assume that key competences at work are multiple, and they feel responsible for a broader range of problems, which leads to their willingness to be flexible (Parker, 2000). For example, Wright and Snell (1998) suggested that these initiatives encourage employees that are more willing to develop their pool of competences rather than those with a narrow vision of their role in the organization, therefore showing higher skill malleability.

Moreover, HPWS may impact HR flexibility through the provision of appropriate rewards. Some authors highlight the relevance of equitable rewards to encourage employees' willingness to move and reallocate as the need arises (i.e., to show functional flexibility). Fluid assignments implicit in the notion of functional flexibility require considerably high inputs from the workforce and organizations should provide commensurate returns in an effort to motivate desired employee movements across tasks and jobs (Dyer \& Shafer, 2002; Noe, 1996). Furthermore, the provision of equitable rewards is an instrument that helps to attract versatile employees because employees with high qualifications, varied knowledge, and multiple abilities may expect to receive appropriate rewards for their competences. This component of HPWS can also motivate employees to engage in flexible behaviors and effective discretionary decision making in response to a variety of internal and external contingencies (MacDuffie, 1995; Wright \& Snell, 1998). Several authors argue that equitable rewards provide employees with the confidence to take initiative and behave flexibly at work because they are aware that the organization will recognize their efforts in proposing creative solutions to new problems (Frenkel, Korczynski, Shire, \& Tam, 1999; Unsworth \& Parker, 2003). In fact, authors such as Morris (1993) indicate that one of the components of 
equitable rewards - performance-related pay - is used as a signal to express organizational intentions and create a flexible and self-motivated workforce. According to Unsworth and Parker (2003), higher initiative and flexibility at work can involve a greater workload, which may produce stress and anxiety in employees if these efforts are not reinforced by equitable rewards. A fair, balanced exchange relationship with the organization enhances feelings of certainty about gaining fair rewards for substantial innovative efforts (Williams, Pitre, \& Zainuba, 2002).

The aforementioned reasoning leads us to propose that a relevant mediating process by which HPWS affect performance is through improvements in the flexibility levels of human resources. Thus, we hypothesize that the reason why HPWS impact firm performance is because they affect HR flexibility, which is a critical determinant of the outcomes the firm achieves. This idea is expressed as follows:

Hypothesis 2: HR flexibility will mediate the relationship between HPWS and organizational performance.

\section{Method}

\section{Data Collection}

The fieldwork for this study took place from May to October 2005 on a sample of Spanish industrial and service companies with 100 or more employees. We used company size to delimit the population because the literature considers that a minimum size is required to identify companies with an explicit or formalized human resource strategy (Lepak \& Snell, 2002). According to this criterion, the population for our study was made up of 3,427 firms in different sectors.

The unit of analysis in our study is the commercial departments of the companies; that is, we are interested in the linkages between HPWS, HR flexibility, and performance related to salespeople in our sample of firms. The nature of work in this department refers not only to the generation of sales but also the creation of strong relationships with customers (Román, Ruiz, \& Munuera, 2002; Wilson, 2000). Nowadays, commercial teams focus on implementing a customer-oriented approach, which implies solving customers' problems, providing opportunities, and adding value to the customer's business over an extended period of time (Flaherty, Dahlstrom, \& Skinner, 1999). In the words of Weitz and Bradford (1999), employees in this area act as boundary spanners by building customer relationships and creating value. In their boundary-spanning roles, salespeople are responsible for making decisions and working with limited supervision, showing differences from internal employees (Chonko, Jones, Roberts, \& Dubinsky, 2002). As Marshall, Moncrief, and Lassk (1999) demonstrated, the commercial function in an organization covers a wide range of activities (these authors identified up to 83 different activities in the sales function across a sample of firms in different sectors). In addition, over the past decade, some new activities have been added to the responsibilities of employees in this function, mostly related to communication, team building, or database management (Marshall et al., 1999). 
The limitation of the study to this area has several advantages. On one hand, as HPWS refer only to one group of employees in the firm, some improvements to the reliability of the HPWS measurement can be made (Delery, 1998). Several scholars have suggested that human resource practices vary with respect to location, type of employee, or business unit. In this regard, Tsui, Pearce, Porter, and Tripoli (1997) provided strong evidence that organizations use different human resource practices for employees in different jobs. Consequently, one informant is unlikely to provide an accurate definition of the human resource practices that correspond to different jobs (Wright \& Gardner, 2003). For the same reason, a general assessment of the human resource practices for the whole workforce would not be appropriate (Lepak \& Snell, 2002). To avoid these problems, some studies have recommended focusing on specific jobs or a group of similar jobs (Delery, 1998).

Furthermore, employees in the commercial department are increasingly relevant to competition in current environments (Slater \& Olson, 2000). The sales or commercial occupation has considerable relevance to the economies of most countries because this function plays an essential role in guaranteeing the success of many firms (Farrell \& Hakstian, 2001). For this reason, enhancing the performance of salespeople is one of the most urgent tasks managers face (Boles, Brashear, Bellenger, \& Barksdale, 2000). However, the notion of salespeople's performance is changing because several external challenges are affecting the commercial function in modern firms: Customers have more information, competition is stronger due to market globalization, and technology is continually becoming more advanced (Ingram, 2004; Román et al., 2002; Wotruba, 1996). In the Spanish context, the commercial function in companies is also facing increasing customer demands, microsegmentation of domestic markets, advances in information technologies and telecommunications, direct-marketing alternatives, and higher competition (Kuster \& Canales, 2006). In these circumstances, contemporary sales forces are under pressure to change and adapt to new circumstances in their daily tasks (Chonko et al., 2002).

We collected data through the administration of structured questionnaires to the commercial managers in the companies. Our analyses included a total of 226 valid responses. Of these companies, $37 \%$ were from service sectors and $63 \%$ from industrial sectors. Regarding organizational size, $49 \%$ of the companies were medium sized (100 to 249 employees) and $51 \%$ were large companies (250 employees or more). The sample error in our study was $\pm 6.3 \%$. This sample error is relatively high, but this is a typical situation in research conducted in Spain, where collaboration between companies and universities is not easily established (Camelo, Martín, Romero, \& Valle, 2004; Valle, Martín, Romero, \& Dolan, 2000). To examine the representativeness of the sample and the risk of nonresponse bias, we compared the characteristics (organizational size) of the population to those of the sample (Short, Ketchen, \& Palmer, 2002). We performed an ANOVA to compare size (number of employees) between the two groups of companies. The result of this analysis $(F=1.313 ; p=.252)$ shows no significant difference and therefore supports the representativeness of the sample.

\section{Measurement}

The appendix provides a detailed description of the measures used in our research. To measure HPWS, we used Snell and Dean's (1992) scale, which covers items related to selective 
staffing, comprehensive training, developmental performance appraisal, and equitable reward systems. As in the original scale, questions in our questionnaire ranged from 1 to 7 , with anchors varying according to the question. Subsequent studies have used this scale and demonstrated the validity of its measurement properties (Whitener, 2001). As described in the definition of HPWS, there should be an internal fit between the previous dimensions. In this study, we operationalize HPWS internal fit as covariation based on factor analysis (Venkatraman, 1989). According to this perspective, the common variation of HPWS dimensions is explained by a latent factor (HPWS) that captures their covariance (Delery, 1998; Dorenbosch, van Veldhoven, \& Poell, 2005; Wood, 1996; Wood \& Albanese, 1995).

We measured HR flexibility with an adaptation of the measurement scales proposed by Volverda (1998) and Verdú (2002) to assess functional flexibility. In measuring skill malleability we followed the suggestions provided by Pulakos et al. (2000) to develop a scale designed to assess the facility with which employees alter their skill base as the need arises. To measure behavior flexibility, we selected a set of items used by Frese et al. (1996) to evaluate job initiative. The resultant HR flexibility scale bears many similarities to other studies that have recently operationalized this concept from the RBV approach (Bhattacharya et al., 2005). The wording of the HR flexibility items incorporates the suggestions provided by several scholars (Delery, 1998; Farrell \& Hakstian, 2001; Huselid et al., 1997; Wright, Smart, \& McMahan, 1995) who state that the features of the workforce can be assessed by a key respondent whose position in the organization enables him or her to rate them. In particular, following Huselid et al. (1997), items in our questionnaires asked these managers to assess the extent to which employees in this department currently possess the capabilities and attributes listed on a scale ranging from 1 (applies to very few employees) to 7 (applies to most of the employees). In this study, we represent HR flexibility as a latent factor that captures the intercorrelations between the previous dimensions.

Concerning organizational performance and in accordance with the description of the unit of analysis in our study, we endeavored to use measures that are more directly related to the commercial department rather than firm performance indicators where other variables (e.g., market trends or competitors movements) may contaminate the results (Challis, Samson, \& Lawson, 2005). Specifically, given the close interaction between employees in this area and the firm's customers, we included customer service effectiveness as an indicator of performance. Prior studies in the HRM field have used this measure (e.g., Borucki \& Burke, 1999; Liao \& Chuang, 2004; Youndt et al., 1996), and it refers to the extent to which relationships with customers are efficient and customers' needs and expectations are fulfilled. As shown in the appendix, the performance measures used in our research are relative because we asked informants to assess their performance over the past 3 years as compared with that of their competitors (Delaney \& Huselid, 1996).

In addition, we considered organizational size and sector as control variables that can account for an association between HPWS and performance (Gerhart, Wright, McMahan, \& Snell, 2000). Following previous studies in the HRM field, we measured size as the logarithmic transformation of the number of employees (Huselid et al., 1997; Youndt et al., 1996). Regarding sector, we differentiated between industrial and service companies (according to the Standard Industrial Classification code) and then created a dichotomous variable, where 1 corresponds to industrial sector companies and 2 to service firms. 


\section{Results}

\section{Analytic Procedures}

We conducted our analyses with structural equation modeling (SEM) using the statistical program EQS 6.1 for Windows (Bentler, 1995). To start with, we carried out a preliminary analysis of our data to assess the issue of common method variance and examine the correlations between the variables included in our research.

Following this, we estimated the measurement models corresponding to our scales so as to analyze their dimensionality, that is, the relationships between latent and observed variables. In doing so, we estimated a set of confirmatory factor analyses (CFAs) that helped us to verify the proposed structure for the HWPS, HR flexibility, and organizational performance scales.

Finally, we tested the structural models corresponding to our hypotheses. In particular, we performed structural models for tests of mediation according to the procedure suggested by Baron and Kenny (1986) and Holmbeck (1997). This procedure involves estimating two structural models. The first corresponds to a direct effect model that tests the effect of the predictors on the dependent variables. In the context of our research, this model allows us to test Hypothesis 1 as it involves estimating the direct effect of HPWS on performance (Figure 1). For mediation to exist, the path coefficients in the direct effect model corresponding to the HPWS-organizational performance linkage $\left(\gamma_{1}\right)$ must be significant to continue to test the mediation effect. The second model is a mediated model that includes the intermediate variable. This model corresponds to our second hypothesis and considers the effects of HPWS on HR flexibility, the influence of HR flexibility on performance, and the direct effect of HPWS on performance (Figure 1). Furthermore, to test whether the mediating effect of HR flexibility is partial or total, we compare the previous mediated model with a constrained model in which the HPWS-performance path $\left(\gamma_{1}\right.$ in the mediated model) is set to zero. This allows us to examine whether the mediated model implies a significant improvement in fit over the constrained model. If there is a total mediating effect of HR flexibility, the addition of the HPWS-performance path to the constrained model should not improve the fit. Alternatively, for total mediation to exist, the previously significant HPWS-performance in the direct effect model $\left(\gamma_{1}\right)$ should be reduced to nonsignificance when the mediator is taken into account in the mediated model (Holmbeck, 1997).

\section{Preliminary Analysis and Correlation Matrix}

As a preliminary step in our analyses, we assessed the issue of common method variance because a single respondent evaluates all the variables in our research. According to Harman's single-factor test (Podsakoff, MacKenzie, Lee, \& Podsakoff, 2003; Podsakoff \& Organ, 1986), if common method variance exists, a single factor will emerge from a factor analysis of all survey items. This test can be performed using a CFA that includes all items from all the constructs in the study in a factor analysis to determine whether most of the vari- 
ance can be accounted for by one general factor (Podsakoff et al., 2003). The results of this CFA (Satorra Bentler $\chi^{2}=212.65 ; d f=77 ; p=.00$; Bentler-Bonnet Non-Normed Fit Index = 0.76; Comparative Fit Index $=0.79$; root mean square error of approximation $=0.10$; normed chi-square $=2.76$ ) indicate that common method variance does not exist in our study because these indices show far from acceptable values.

Table 1 shows the means, standard deviations of all the variables included in our analyses, and the correlations between them. This matrix includes 19 variables corresponding to the components of HPWS (V1-V4), HR flexibility (V5-V7), organizational performance (V8-V14), and control variables (V15-V16). Furthermore, variables V17 (organizational performance), V18 (HPWS), and V19 (HR flexibility) derive from averaging the corresponding scale items.

\section{Structure of HPWS, HR Flexibility, and Organizational Performance}

We used CFAs to evaluate the measurement models included in this study, that is, to examine the dimensionality of our scales. The purpose of this analysis is to describe how well the observed indicators serve as a measurement instrument for the latent variable, and according to SEM methodology, it is a necessary step before testing the causal relationships between the latent variables.

\section{Dimensionality of the HPWS Scale}

For the HPWS scales, we performed a confirmatory factor analysis for each HPWS dimension. For the selective staffing, comprehensive training, and developmental appraisal scales, the goodness-of-fit indices fell within the commonly accepted limits, thus confirming the unidimensionality of these scales, namely, items constituting each HPWS scale represent the same theoretical construct. However, our analyses did not support the unidimensionality of the equitable reward system scale, with goodness-of-fit indices much too low for a well-fitting model. We therefore performed an exploratory factor analysis with the items corresponding to this scale. The exploratory factor analysis showed that the items load on two different factors (Table 2). As a result, we split the equitable reward systems scale into two subscales: one corresponding to the more subjective evaluation of internal and external equity (made up of three items) and the other subscale corresponding to a performance-based pay item.

In summary, we considered five components of HPWS for subsequent analyses, namely, selective staffing, comprehensive training, developmental performance appraisal, equitable reward systems, and performance-based pay. In addition, we estimated a CFA on the overall HPWS scale, including all items for all five dimensions. This model includes the HPWS dimensions as intercorrelated latent variables. The fit indices corresponding to this CFA show acceptable values (Table 3), thus confirming the proposed dimensionality.

To test whether there is internal fit among the HPWS components, we performed a CFA (Wood \& Albanese, 1995) including HPWS as a second-order latent factor underlying the first-order latent variables corresponding to the HPWS dimensions (Figure 2). Theory argues for a higher-order factor (HPWS) that is considered accountable for the first-order factors (selective staffing, comprehensive training, developmental performance appraisal, equitable 


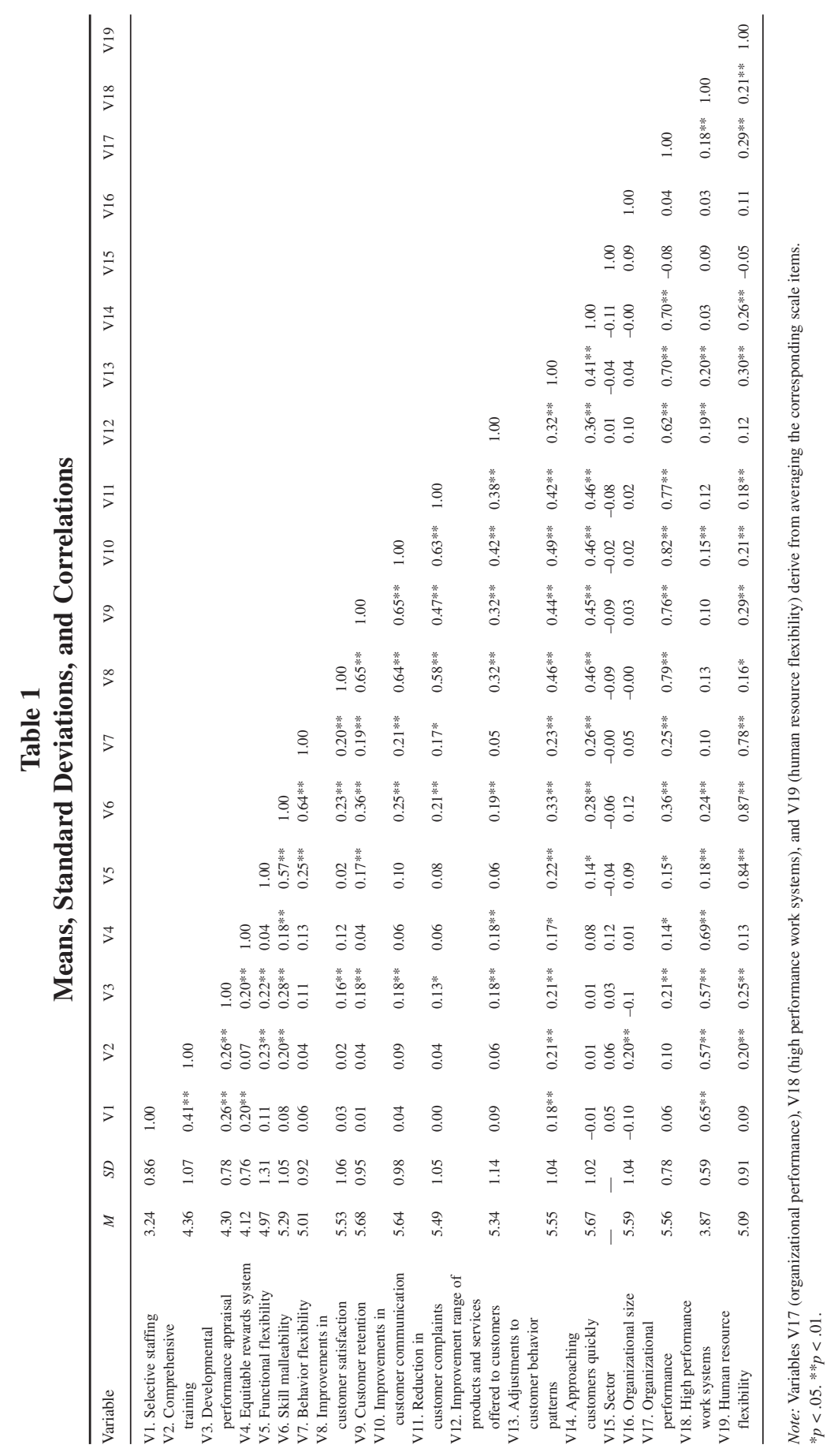




\section{Table 2}

\section{Exploratory Factor Analysis of the Equitable Reward System Scale: Item Loadings}

\begin{tabular}{|c|c|c|}
\hline Variable & Factor 1 & Factor 2 \\
\hline $\begin{array}{l}\text { How would you rate pay levels in this unit relative to other firms? } \\
\qquad(1=\text { low } ; 4=\text { same } ; 7=\text { high })\end{array}$ & .55 & -.02 \\
\hline $\begin{array}{l}\text { How would you rate the pay levels in this unit relative to past years? } \\
(1=\text { lower than past } 4=\text { same } ; 7=\text { higher than past })\end{array}$ & .51 & .11 \\
\hline $\begin{array}{l}\text { How closely is pay tied to individual performance, in terms of } \\
\text { percentage of the salary? }(1=<10 \% ; 2=10 \%-20 \% ; 3=20 \%-30 \% \text {; } \\
\quad 4=30 \%-40 \% ; 5=40 \%-50 \% ; 6=50 \%-60 \% ; 7=>60 \%)\end{array}$ & .00 & .47 \\
\hline $\begin{array}{l}\text { How wide is the range in pay across members in this department? } \\
(1=\text { narrow } 4=\text { moderate } ; 7=\text { very wide })\end{array}$ & .28 & -.04 \\
\hline
\end{tabular}

Note: Bold indicates that the variable loads into Factor 1 or Factor 2.

Table 3

Fit Indices ${ }^{\text {a }}$ for the Confirmatory Factor Analyses (CFAs)

\begin{tabular}{|c|c|c|c|c|c|c|c|}
\hline Model & $\chi_{\mathrm{SB}}^{2 \mathrm{~b}}$ & $d f$ & $p$ & $\begin{array}{l}\text { Bentler- } \\
\text { Bonnet } \\
\text { Non- } \\
\text { Normed } \\
\text { Fit Index }\end{array}$ & $\begin{array}{l}\text { Comparative } \\
\text { Fit Index }\end{array}$ & $\begin{array}{c}\text { Root Mean } \\
\text { Square Error of } \\
\text { Approximation }\end{array}$ & $\begin{array}{c}\text { Normed } \\
\text { Chi-Square }\end{array}$ \\
\hline $\begin{array}{l}\text { High } \\
\text { performance } \\
\text { work systems } \\
\text { (HPWS) scale } \\
\text { (correlated } \\
\text { factors) }\end{array}$ & 254.28 & 220 & .06 & .91 & .93 & .03 & 1.16 \\
\hline $\begin{array}{l}\text { HPWS } \\
\text { second-order } \\
\text { CFA } \\
\text { (internal fit) }\end{array}$ & 272.72 & 225 & .02 & .88 & .90 & .03 & 1.21 \\
\hline $\begin{array}{l}\text { Human resource } \\
\qquad \text { (HR) flexibility } \\
\text { scale (correlated } \\
\text { factors) }\end{array}$ & 55.43 & 41 & .07 & .97 & .98 & .04 & 1.35 \\
\hline $\begin{array}{l}\text { HR flexibility } \\
\text { second-order } \\
\text { CFA }\end{array}$ & 55.44 & 41 & .07 & .96 & .98 & .04 & 1.35 \\
\hline $\begin{array}{l}\text { Organizational } \\
\text { performance } \\
\text { scale }\end{array}$ & 15.65 & 14 & .34 & .99 & .99 & .02 & 1.18 \\
\hline
\end{tabular}

Human resource (HR) flexibility scale (correlated factors) 55.43 41.07 .97 .98 .041 .35 HR flexibility secondorder CFA 55.44 41.07 96 98 .04 1.35 Organizational performance scale $15.65 \quad 14.34 .99 .99 .02 \quad 1.18$ a. Recommended values for the fit indices: Bentler-Bonnet Non-Normed Fit Index $\geq 0.90$; Comparative Fit Index $\geq$ 0.90; root mean square error of approximation $\leq 0.05$; normed chi-square between 1.0 and 5.0.

b. We used the Satorra Bentler chi-square $\left(\chi_{\mathrm{SB}}^{2}\right)$ due to the non-normality of the variables. 
Figure 2

High Performance Work Systems (HPWS) Second-Order Confirmatory Factor Analysis

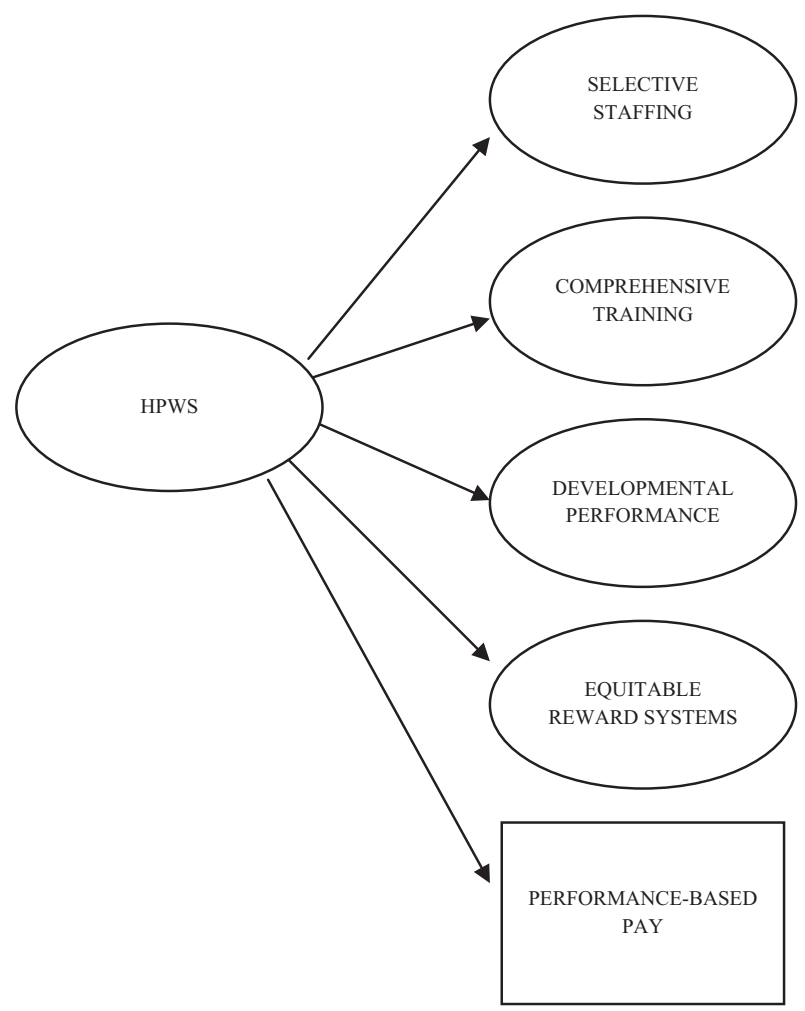

reward systems, and performance-based pay) (Gallie et al., 2001; Vandenberg et al., 1999). This model essentially has the same factor structure as the aforementioned model with HPWS as intercorrelated latent variables. However, the higher-order factor (HPWS) namely, second-order factor-is hypothesized as accounting for or explaining all variance and covariance related to the first-order factors. The first-order factors now operate as dependent variables, which means that their variances and covariances are no longer estimated parameters in the model. The CFA depicted in Figure 2 hypothesizes that (a) HPWS can be conceptualized in terms of four factors (selective staffing, comprehensive training, developmental performance appraisal, equitable reward systems) and one observable indicator (performance-based pay), (b) each observed variable will have a nonzero loading on the factor it was designed to measure and zero loadings for all other factors, (c) error terms associated with each observed variable will be uncorrelated, (d) the first-order factors will be correlated, (e) covariation among the first-order factors and the observable variable will be explained fully by their regression onto the second-order factor.

An appropriate fit for this model implies that such variation and covariation is accounted for by the second-order factor, which according to the idea of fit as covariation, lends 
Figure 3

Human Resource (HR) Flexibility Second-Order Confirmatory Factor Analysis

support to the existence of internal fit among the HPWS dimensions (Venkatraman, 1989). This model shows a good fit, as indicated by the $\chi^{2}$ and the fit indices (Table 3 ). This result can be interpreted as evidence of an underlying HPWS approach that explains any association that may exist between the set of practices associated with HPWS, therefore verifying the existence of an internal fit among the HPWS dimensions.

We evaluated the reliability of the HPWS scales through a composite reliability (c.r.) index, which is often applied in research using SEM (Fornell \& Larcker, 1981). This index takes into account the relative importance of each indicator in the factor to which it belongs and shows values of 0.56 for the selective staffing scale, 0.74 for comprehensive training, 0.66 for developmental performance appraisal, and 0.54 for the first subscale of equitable reward systems.

To reduce the complexity of our structural models for tests of direct and mediated effects, we considered it appropriate to reduce the items corresponding to each HPWS dimension into a single value by calculating the mean value of these items. The resulting five variables act as observable indicators of a first-order factor corresponding to HPWS.

\section{Dimensionality of the HR Flexibility Scale}

Regarding the HR flexibility scale, we first verified the unidimensionality of each flexibility dimension by estimating three single-factor CFAs, which showed appropriate fit indices. We then estimated a CFA comprising the three HR flexibility dimensions as interrelated latent variables shows a good fit (Table 3). Composite reliability indices are higher than 0.7 for the three scales. Similarly to HPWS, we assume that there is an underlying HR flexibility higher-order factor that captures the intercorrelations among the flexibility dimensions. 
Figure 3 depicts a second-order HR flexibility confirmatory factor analysis measurement model. The single-headed arrows leading from the second-order factor of HR flexibility to each of its first-order factors (functional flexibility, skill malleability, behavior flexibility) indicate the prediction of these dimensions from the higher-order HR flexibility factor.

Fit statistics associated with this model verify the proposed structure of the HR flexibility construct (Table 3). We also reduced the items corresponding to each HR flexibility dimension into a single value by calculating the mean value of these items.

\section{Dimensionality of the Organizational Performance Scale}

Finally, the CFA with the seven performance indicators (Table 3) confirms that these items belong to a single factor, with high reliability (c.r. $=0.86)$.

\section{Testing the Structural Models}

As regards the estimation of the structural models corresponding to our hypotheses, the $\chi^{2}$ for the direct effect model is not statistically significant and the values of the fit indices fall within the commonly accepted limits (Table 4). The results confirm that once the control variables have been introduced in the equations, the value of the structural parameter $\gamma_{1}$ corresponding to the influence of HPWS on performance is statistically significant with a value of 0.27 , as shown in the standardized solution of this model (Table 5). Thus, our analyses demonstrate that HPWS impact organizational performance, corroborating Hypothesis 1 and lending support to previous studies that demonstrate the relevance of adopting HPWS to firm success (e.g., Delaney \& Huselid, 1996; Huselid, 1995; Huselid et al., 1997; Koch \& McGrath, 1996). In addition, because we operationalized HPWS as a latent variable, our results highlight the positive effects of a synergistic system of HPWS practices (i.e., showing internal fit) on performance. The results of this model indicate that there is a relationship between HPWS and performance, which is a necessary condition for estimating the mediated model, corresponding to Hypothesis 2.

The estimation of the mediated model also shows a good fit, according to the values of the $\chi^{2}$ and the fit indices (Table 4). Structural coefficients corresponding to this model appear in Table 6 and Figure 4. Of crucial interest is the fact that HPWS significantly affect HR flexibility $\left(\gamma_{4}=0.40\right)$ and HR flexibility influences firm performance $\left(\beta_{1}=0.31\right)$, which confirms the mediating role of HR flexibility in the HPWS-performance relationship, as predicted in Hypothesis 2.

We then compared this model with a model in which the HPWS-performance linkage is constrained to zero. The fit indices for the constrained model appear in Table 4. A $\chi^{2}$ difference test between these two models reveals that the difference in the $\chi^{2}$ is not statistically significant $(p=.11)$. Hence, the HPWS-performance relationship in the mediated model does not significantly improve the fit of the constrained model, thus evidencing the total mediating effect of HR flexibility in this model.

In addition, we observe that when HR flexibility is introduced in the equation (in the mediated model), both the structural coefficient corresponding to the direct effect of HPWS 


\section{Table 4}

Fit Indices for the Structural Models

\begin{tabular}{cccccccc}
\hline Model & $\chi_{\mathrm{SB}}^{2}$ & $d f$ & $p$ & $\begin{array}{c}\text { Bentler- } \\
\text { Bonnet } \\
\text { Non- } \\
\text { Normed } \\
\text { Fit Index }\end{array}$ & $\begin{array}{c}\text { Comparative } \\
\text { Fit Index }\end{array}$ & $\begin{array}{c}\text { Root Mean } \\
\text { Square Error of } \\
\text { Approximation }\end{array}$ & $\begin{array}{c}\text { Normed } \\
\text { Chi-Square }\end{array}$ \\
\hline $\begin{array}{c}\text { Direct effect } \\
\text { model }\end{array}$ & 92.99 & 75 & .08 & .96 & .97 & .03 & 1.24 \\
$\begin{array}{c}\text { Mediated } \\
\text { model } \\
\begin{array}{c}\text { Constrained } \\
\text { model }\end{array}\end{array}$ & 145.73 & 115 & .03 & .95 & .96 & .03 & 1.27 \\
\hline
\end{tabular}

Table 5

Standardized Solution for the Direct Effect Model

\begin{tabular}{|c|c|c|c|}
\hline Variable & $\begin{array}{l}\text { High Performance } \\
\text { Work Systems } \\
\text { (HPWS) }\end{array}$ & $\begin{array}{r}\text { Organizational } \\
\text { Performancea }\end{array}$ & Errors \\
\hline Selective staffing & .35 & & .94 \\
\hline Comprehensive training & .32 & & .95 \\
\hline $\begin{array}{l}\text { Developmental performance } \\
\text { appraisal }\end{array}$ & .78 & & .62 \\
\hline Equitable rewards system & .31 & & .95 \\
\hline Performance-based pay & .20 & & .98 \\
\hline $\begin{array}{l}\text { Improvements in customer } \\
\text { satisfaction }\end{array}$ & & .79 & .62 \\
\hline Customer retention & & .76 & .66 \\
\hline $\begin{array}{l}\text { Improvements in customer } \\
\text { communication }\end{array}$ & & .83 & .56 \\
\hline Reduction customer complaints & & .72 & .69 \\
\hline $\begin{array}{l}\text { Improvement in range of products } \\
\text { and services offered to customers }\end{array}$ & & .48 & .88 \\
\hline $\begin{array}{l}\text { Adjustments to customer } \\
\text { behavior patterns }\end{array}$ & & .61 & .79 \\
\hline Approaching customers quickly & & .59 & .80 \\
\hline \multicolumn{4}{|c|}{ Organizational performance $=0.27 * \mathrm{HPWS}-0.08 \mathrm{SECTOR}+0.03 \mathrm{SIZE}+0.96$} \\
\hline
\end{tabular}

$* p<.05$. 
Table 6

Standardized Solution for the Mediated Model

\begin{tabular}{|c|c|c|c|c|}
\hline Variable & $\begin{array}{c}\text { High } \\
\text { Performance } \\
\text { Work Systems } \\
\text { (HPWS) }\end{array}$ & $\begin{array}{l}\text { Human } \\
\text { Resource } \\
\text { (HR) } \\
\text { Flexibility }\end{array}$ & $\begin{array}{l}\text { Organizational } \\
\text { Performance }\end{array}$ & Errors \\
\hline Selective staffing & .35 & & & .94 \\
\hline Comprehensive training & .35 & & & .94 \\
\hline Developmental performance appraisal & .73 & & & .68 \\
\hline Equitable rewards system & .34 & & & .94 \\
\hline Performance-based pay & .19 & & & .98 \\
\hline Functional flexibility & & .59 & & .81 \\
\hline Skill malleability & & .96 & & .27 \\
\hline Behavior flexibility & & .66 & & .75 \\
\hline Improvements in customer satisfaction & & & .78 & .62 \\
\hline Customer retention & & & .76 & .65 \\
\hline Improvements in customer communication & & & .83 & .56 \\
\hline Reduction customer complaints & & & .72 & .69 \\
\hline $\begin{array}{l}\text { Improvement in range of products and services } \\
\text { offered to customers }\end{array}$ & & & .48 & .88 \\
\hline Adjustments to customer behavior patterns & & & .61 & .79 \\
\hline Approaching customers quickly & & & .59 & .81 \\
\hline HR flexibility $=0.40 * *$ HPWS +0.92 & & & & \\
\hline
\end{tabular}

Organizational performance $=0.16 \mathrm{HPWS}+0.31^{* *} \mathrm{HR}$ FLEXIBILITY $-0.09 \mathrm{SECTOR}+0.03 \mathrm{SIZE}+0.92$ $* * p<.01$.

on performance and its statistical significance diminish, leading to a nonsignificant effect of HPWS on the dependent variable $\left(\gamma_{1}=0.16\right)$. This result can be also interpreted as evidence of a total mediating effect of HR flexibility in the relationship between HPWS and performance. The mediated model contribution to the HPWS-performance linkage lies in the analysis of HR flexibility as an intermediate mechanism that explains the relationship and that helps to enhance the information provided by the direct effect model.

\section{Discussion}

We found evidence for our sample of companies that HPWS have a positive influence on firm performance. These results support the strategic relevance of HPWS for the firm and coincide with previous empirical studies in the field (e.g., Arthur, 1994; Huselid et al., 1997). However, we assume that the direct effect of HPWS on organizational performance may be due to the existence of intermediate variables that are affected by HPWS and that in turn 
Figure 4

Results of the Mediated Model

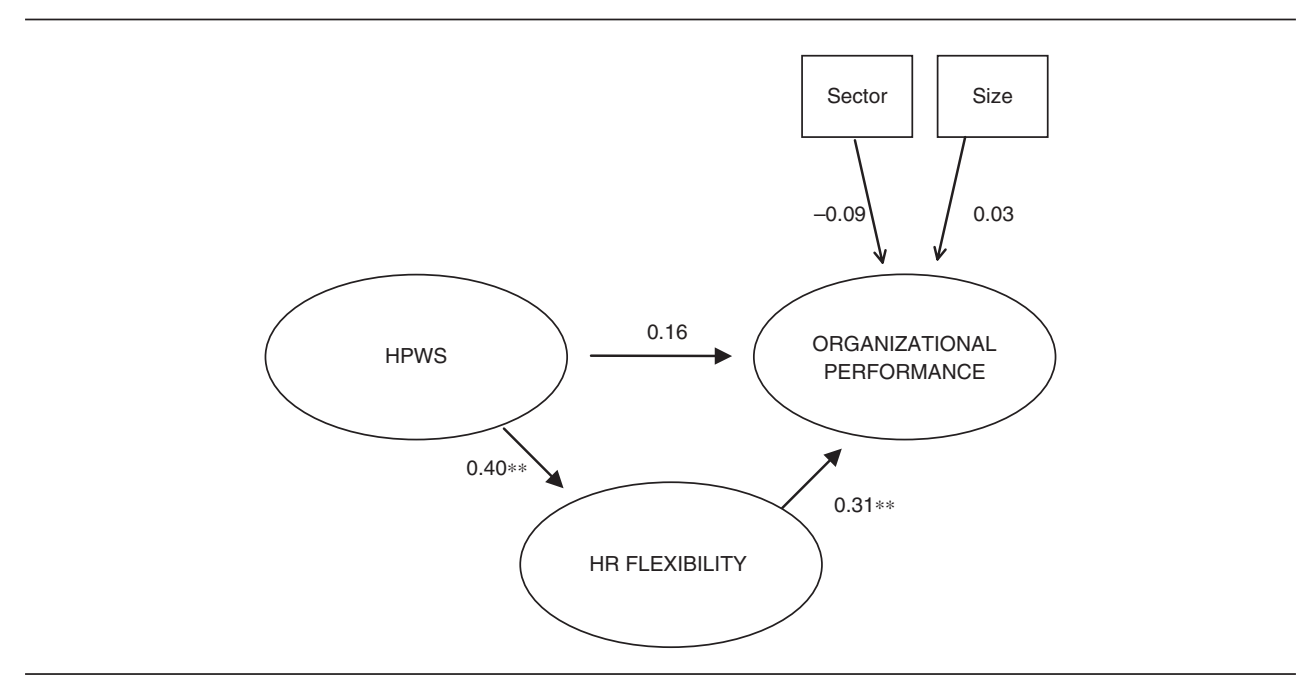

Note : HPWS $=$ high performance work systems; HR = human resource.

$* p<.05 . * * p<.01$.

influence organizational performance. By modeling these intervening variables along with their antecedents, researchers can avoid omitted variables and certain threats that accompany such omissions (e.g., overestimates of HPWS on organizational performance) (Bagozzi, 1994; Becker \& Huselid, 2006). This concern has guided recent empirical studies in the HRM field that try to explore what happens between HPWS and organizational performance (e.g., Park et al., 2003; Ramsay et al., 2000).

Similarly to the studies mentioned earlier, our work is embedded in the "next generation" of human resource management and offers a deeper study of how and why HPWS affect organizational performance (Wright, 2003). In particular, we demonstrate the relevance of HR flexibility as a mediator variable between HPWS and organizational performance. According to our results, when we introduce HR flexibility in the mediated model, the effect of HPWS on organizational performance becomes statistically insignificant. This result can be interpreted as meaning that HPWS mainly exert their influence on firm performance through HR flexibility. In other words, HPWS no longer affect organizational performance when HR flexibility has been controlled for. Therefore, HR flexibility is one of the variables that contribute to a deeper insight into the processes through which HPWS influence firm results. We believe that these results contribute to the HPWS literature in several ways.

First, support for the hypothesized mediating role of HR flexibility lends credence to the RBV arguments highlighting the relevance of creativity and agility in organizational resources for the firm's performance (Sanchez, 1997, 2004). Our work goes beyond the adaptive concept of HRM, which assumes that firms have an a priori strategy and the main 
challenges lie in employee contribution to strategy implementation (Colbert, 2004). The traditional adaptive vision justifies the relevance of aspects such as employees' commitment to the firm's goals or their current skill base as intermediate variables between HPWS and organizational performance, which was the focus of prior empirical studies (e.g., Moynihan et al., 2001; Ramsay et al., 2000). However, from the RBV perspective, researchers should also consider questions related to employees' flexibility in explaining the reason why HPWS impact firms' outcomes. Results concerning the indirect effect of HPWS on organizational performance through HR flexibility in our study confirm this belief and also lend support for critical theoretical studies in the HRM literature, which proposes that HR flexibility is one of the mechanisms through which HPWS affect firm performance (e.g., Guest, 1987; Wright \& Snell, 1998).

Second, prior empirical evidence has not fully clarified the processes between HPWS and organizational performance in that it has only found partial or weak mediating effects (e.g., Katou \& Budhwar, 2006; Park et al., 2003; Ramsay et al., 2000; Sun et al., 2007). Along with our results, HR flexibility has to date been an omitted mediating variable that can complement prior empirical evidence and help researchers improve the information available in their models and therefore advance the examination of the intermediate mechanisms between HPWS and measures of firm performance.

Third, the estimation of the mediated model corresponding to Hypothesis 2 provides some partial results that deserve mention. On one hand, we observed that the effect of HR flexibility on organizational performance is positive and statistically significant. This result confirms that as employees show flexibility at work, by manifesting flexibility in skills and behaviors, the firm's results increase. Our conclusions complement prior discussions on the positive effects of HR flexibility for firm performance, most of which had to date arisen at a theoretical level (e.g., Campbell, 2000; Wright \& Snell, 1998). On the other hand, the second partial result stemming from our mediating model refers to the impact that HPWS have on HR flexibility, as recent studies in the field suggest (Bhattacharya et al., 2005). This result confirms the ideas provided by earlier proponents of HPWS in that one of the consequences of HPWS in terms of employees' performance at work is an improvement in their flexibility (e.g., Guest, 1987).

Fourth, we aim to integrate the individual- and organizational-level approaches to studying HR flexibility by recognizing that HR flexibility arises out of individual skills and behaviors that can be fostered by HPWS as a set of human resource practices consciously designed and implemented by the firm. Moreover, our research demonstrates that both the content and process effect of human resource management that Bhattacharya et al. (2005) suggested can appear simultaneously in the firm. According to these authors, HR flexibility is an indicator of the firm's ability to react and adapt to changing conditions (process effect), whereas HPWS represent the existence of specific practices in the firm that are associated with organizational performance (content effect). Our research verifies that both of these aspects and their interrelations (i.e., influence of HPWS on HR flexibility) are essential to attain superior organizational performance.

Fifth, the current study contributes to the HR flexibility literature by adopting a multidimensional definition of HR flexibility from the RBV premises that extends the conceptualizations proposed by previous scholars (e.g., Kara, Kayis, \& O'Kane, 2002; Shafer et al., 2001). By considering questions such as skill malleability, the RBV perspective introduces 
a proactive element into the HR flexibility concept, focused on the change-initiating role of employees that allows organizations to anticipate future external changes. HR flexibility from the RBV differs from previous conceptualizations of workforce flexibility, which mainly focus on employee versatility or functional flexibility (Karuppan, 2004; Molleman \& Slomp, 1999) and therefore on employees' ability to move or reallocate once a triggering episode has occurred. This definition of HR flexibility has been defended from a theoretical perspective (RBV), and our research together with that of Bhattacharya et al. (2005) provide initial attempts to introduce this measure into empirical researches.

Sixth, this work is one of the first to examine the intermediate mechanisms that explain the relevance of HPWS for firm outcomes in the Spanish context, where empirical research has mainly focused on the direct effects between these variables (e.g., De Saá \& García, 2001; Ordiz, 2004; Peña \& Hernández, 2006; Rodríguez, 2003) without providing much information about the causalities involved. In addition, and taking into account the unit of analysis in the present study, our research verifies the relevance to firm success of employees from the commercial area. This finding is consistent with the suggestions of MacKenzie, Podsakoff, and Ahearne (1998), who highlighted the relevance for firms of flexibility in this particular group of employees. Employees in commercial departments shape the nature of the interdependences between the organization and its customers, which has emerged as a competitive factor in Spanish firms (Kuster \& Canales, 2006; Verano, Melián, \& García, 2006).

Finally, we operationalize HPWS as a latent factor, recognizing that the complementarities among the HPWS practices rather than isolated HPWS components influence HR flexibility and in turn organizational performance (Ichniowski et al., 1997). We represent HPWS as a latent variable that captures the congruence between several human resource practices. These results are similar to findings of previous studies, such as De Menezes and Wood (1996), MacDuffie (1995), or Youndt et al. (1996), that demonstrated the existence of a common factor underlying the use of particular human resource practices. In this vein, our study complements prior empirical studies on the intermediate mechanisms (e.g., Fey et al., 2000; Paul \& Anantharaman, 2003), which examined isolated relationships among HPWS practices, employee outcomes, and performance.

\section{Managerial Implications}

Our study has implications for managers. Results on the mediating model demonstrate that HR flexibility is a relevant element that explains why HPWS enhance organizational performance. Our research implies that managers are able to verify whether or not their firm's human resource strategy is contributing to firm performance by observing changes in employee flexibility. According to our results, even if the HR strategy does not show a direct causal connection with organizational performance, it can significantly influence organizational outcomes indirectly, through HR flexibility. When managers implement new human resource strategies, they should take into account that variables related to employee flexibility mediate the effect of HPWS on firm performance. If this is the case, managers are encouraged to check the design of the human resource strategies implemented in the firm by taking the most appropriate approach of targeting HR investments in those practices that 
influence HR flexibility. In a related vein, a further notable finding of our study is the simultaneous effect of HPWS components that influence HR flexibility, which is in accordance with Ostroff and Bowen's (2000) suggestions that the stronger (i.e., internally consistent) the human resource system is, the more significant effects it will have for employee outcomes. These results provide several orientations to managers when selecting the human resource practices that work together and that can benefit the firm's results through HR flexibility.

Another relevant finding of interest for managers is the need to expand the job performance concept in the firm by including HR flexibility-related questions, such as employee abilities to engage in broad, open-ended, and interdependent roles that differ from a traditional conception of job performance centered on the effective performance of a set of specified tasks (Campbell, 2000; Parker, 2000). Aspects such as the provision of new ideas or the ability to learn should become part of the labor performance notion (Ilgen \& Pulakos, 1999; Murphy, 1999). This question also has implications for the design of specific HR procedures. In particular, we recommend including employee flexibility indicators as additional effectiveness criteria used in the performance appraisal processes. Similarly, the relevance of HR flexibility in the HPWS-organizational performance relationship recommends the consideration of employee flexible features when recruiting new employees, for example through the examination of the candidate's willingness to adapt to new circumstances in the staffing processes by using psychological tests or in-depth interviews.

Our study employs a measure of the HR flexibility concept that is theoretically driven, grounded, and integrative, which can be useful in the HR audit processes aimed at evaluating the efficacy of the human resource function when promoting employee flexibility. This measure can provide valuable information for firms, enabling them to more easily identify where improvements may be needed in the flexibility of the workforce.

\section{Limitations and Directions for Future Research}

This study has certain limitations that should be highlighted. As regards the methodology used in the empirical research, we only considered the opinions of one person (commercial manager) on employee flexibility. Future research might compare this measure of HR flexibility with employees' self-rating evaluations of their own flexibility.

Moreover, this article focuses on a single employee outcome (HR flexibility) as a mediator variable, thus ignoring the potential interrelationships between this variable and other relevant employee outcomes, such as employee commitment, skills, or job satisfaction. As Evans and Genadry (1999) noted, future studies should analyze the relevance of HPWS on the tensions that need to be managed as organizations wrestle with achieving favorable returns in the current context while preparing appropriately for challenges of the new one. That is, an interesting angle would be to observe how the relevance of HR flexibility as a mediating variable varies when combined with other employee outcomes. Hence, further questions emerge, such as: Are employees who perform well in a set of established tasks equally ready to face challenging external conditions? Does proficiency in the performance of daily jobs constitute a source of motivation for employees to engage in adaptive roles? The comparison between the reactive and proactive sides of employee performance would 
contribute to advancing understanding of the relevance of employee outcomes in the HPWS-firm performance linkage.

In addition, the mediating model that we propose refers to employees in commercial departments. Although this is a relevant group of employees in modern firms (Slater \& Olson, 2000), these analyses should be replicated in other organizational areas. The increasing challenges that employees in the commercial function have to face in their daily tasks (Ingram, 2004; Román et al., 2002; Wotruba, 1996) can justify the finding that HPWS only influence performance through HR flexibility (i.e., that a total mediating effect of HR flexibility exists). By assessing the proposed relationships in different functions within the firm, researchers could determine whether the relevance of HR flexibility as a mediator mechanism depends on employees' positions in the firm or the characteristics of their job. This question reveals a need to consider environmental dynamism in the proposed model because this variable determines the relevance of HR flexibility for firm performance. Thus, the replication of the model in other settings can help to advance in the consideration of HR flexibility as a mediator variable. Future research could include the environmental characteristics as moderator variables in the proposed model.

Moreover, we believe that further efforts should be made to reach a consensus on which specific practices define HPWS as well as the importance of considering "bundles" of practices in this debate. A shift from a practice-oriented to a bundle-oriented perspective of HPWS would provide a more global interpretation of this strategy, which can help to integrate discrepancies identified in previous conceptualizations of HPWS.

Finally, we suggest analyzing the tensions between the HR flexibility concept presented in our research and other definitions of the term to clarify the relevance of HR flexibility as a mediator variable in the HPWS-organizational performance linkage. By taking the RBV as the framework for defining HR flexibility, this concept is conceived in our study as an internal feature of the firm. However, reality shows us that not all firms have faith in this approach. A large proportion of firms rely on temporary contracts and part-time work as the predominant approach in fostering competitiveness through HR flexibility. This second approach of HR flexibility consists of human resource practices that seek numerical flexibility (Atkinson, 1984; McIlroy, Marginson, \& Regalia, 2004; Michie \& Sheehan, 2001, 2005; Valverde et al., 2000). Although the two HR flexibility approaches are conceptually different, the issue of whether they are mutually exclusive in business practice has still not been resolved (Cappelli \& Newmark, 2004; Kalleberg, 2001; Lepak et al., 2003; Lepak \& Snell, 2002; Tüselmann, 1996) and scholars should determine whether they are complementary or exclusive as mediating variables in the proposed model. 


\section{Appendix \\ Questionnaire Measurement Scales}

\section{High Performance Work Systems}

\section{Selective Staffing}

- How extensive is the employee selection process for a job in this department? $(1=$ not extensive: use of few staffing techniques; 7 = very extensive: use of many different techniques)

- How long does it take to select someone for a position in this department once the job becomes open? $(1$ = short: less than 1 week; 4 = medium: about 6 months; 7 = long: more than 1 year $)$

- How many people are involved in the selection decision? $(1=1$ person; $7=7$ persons $)$

- How much money is generally spent in selecting people for a job, as a percentage of the firm's profits? $(1=$ very little $; 4=$ moderate amount $; 7=$ great deal $)$

- How many applicants are screened for each person hired for a job $(1=1 ; 7=20$ or more $)$

\section{Comprehensive Training}

- How formal or structured is the training processes in this department? $(1=$ very unstructured; 7 = very structured

- What percentage of employees in your department has received training this past year? $(1=0 \%$; $4=50 \% ; 7=100 \%$ )

- On average, how many hours of formal training does a typical member of your department receive per year? $(1=0$ hours; $7=>60$ hours $)$

- How many different kinds of training does a typical member of your work unit receive per year? $(1=$ very few $; 7=$ wide variety $)$

- How much money is generally spent on training individuals, as a percentage of the firm's profits? $(1=$ very little $; 4$ = moderate amount 7 = great deal $)$

- Do you feel training is viewed as a cost or as an investment in your department? $(1=$ viewed as a cost 7 = viewed as an investment)

\section{Developmental Performance Appraisal}

- What percentage of employees in your department is covered by performance appraisal systems? $(1=10 \%$ of employees or less $; 4=40 \%$ of employees $; 7=70 \%$ of employees or more $)$

- How would you describe the performance standards in your department? $(1=$ fixed; $7=$ flexible)

- How much do employees participate in goal setting and appraisal? $(1=$ very little $; 4=$ moder ate amount; 7 = great deal)

- How often is performance discussed with employees? $(1=$ rarely; $4=$ occasionally; 7 = daily $)$

- Do discussions focus on present performance or future performance? $(1=$ present; $7=$ future $)$

- When performance is discussed with employees in this department, how much emphasis is placed on finding avenues of personal development for an employee? $(1=$ very little $; 4=$ moderate amount; 7 = great deal) 
- How closely are pay raises, promotions, etc. tied to performance appraisal in this department? $(1=$ not closely $; 4=$ moderately $; 7=$ very closely $)$

- How would you describe the approach used to discuss performance? $(1=\mathrm{tell} / \mathrm{sell} ; 4=\mathrm{tell} / \mathrm{lis}$ ten; 7 = problem solving)

- How many people provide input to the performance evaluation of each employee in the department? $(1=1 ; 7=7$ or more $)$

\section{Equitable Reward Systems}

- How would you rate pay levels in this unit relative to other firms? $(1=$ low; $4=$ same $; 7=$ high $)$

- How would you rate the pay levels in this unit relative to past years? $(1=$ lower than past; $4=$ same; 7 = higher than past)

- How wide is the range in pay across members in this department? $(1=$ narrow; $4=$ moderate; $7=$ very wide)

\section{Performance-Based Pay}

- How closely is pay tied to individual performance, in terms of percentage of the salary? $(1=<$ $10 \% ; 2=10 \%-20 \% ; 3=20 \%-30 \% ; 4=30 \%-40 \% ; 5=40 \%-50 \% ; 6=50 \%-60 \% ; 7=>60 \%$ )

\section{Human Resource Flexibility}

(Likert type 7-point scale, 1 = applies to very few employees; 7 = applies to most of the employees)

\section{Functional Flexibility}

- Our employees can switch to new jobs with similar responsibilities to their current jobs within a short time.

- Our employees can switch to more qualified jobs within a short time.

- Employees in our department have multiple skills that can be applied to tasks corresponding to other jobs.

\section{Skill Malleability}

- Employees in this department try to constantly update their skills and abilities.

- Employees in this department learn new procedures and processes introduced in their jobs within a short period.

- Employees in this department anticipate future skill requirements that may be needed to perform their jobs.

- When employees in this department are not able to perform a specific task, they quickly learn how to do it. 


\section{Behavior Flexibility}

- When employees detect problems in performing their jobs, they voluntarily try to identify the causes of these problems.

- Most of the changes that have taken place in this department were introduced by employees.

- Employees in this department act efficiently when a problem emerges, even in cases in which they do not have full information about the problem.

- Employees in this department act efficiently under uncertain and ambiguous circumstances.

\section{Organizational Performance (Customer Service Effectiveness)}

(Likert type 7-point scale, $1=$ worse than our competitors; $4=$ equal to our competitors; $7=$ much better than our competitors)

- Improvements in customer satisfaction

- Customer retention

- Improvements in the communication with customers

- Reduction in the number of complaints or claims from customers

- Improvements in the range of products and services offered to our customers

- Being able to adjust to customers' behavior patterns

- Approaching customers quickly

\section{Control Variables}

- Sector

- Organizational size (logarithmic transformation of the number of employees)

\section{References}

Amit, R., \& Schoemaker, P. 1993. Strategic assets and organizational rent. Strategic Management Journal, 14: $33-46$.

Applebaum, E., Bailey, T., Berg, P., \& Kalleberg, A. 2000. Manufacturing advantage: Why high performance work systems pay off. Ithaca, NY: ILR Press.

Arthur, J. B. 1992. The link between business strategy and industrial relations systems in American steel minimills. Industrial and Labor Relations Review, 45: 488-506.

Arthur, J. B. 1994. Effects of human resource systems on manufacturing performance and turnover. Academy of Management Journal, 37: 670-687.

Arulampalam, W., \& Booth, A. L. 1998. Training and labour market flexibility: Is there a trade-off? British Journal of Industrial Relations, 36: 521-536.

Atkinson, J. 1984. Manpower strategies for flexible organisations. Personnel Management, 16(8): 28-31.

Bagozzi, R. P. 1994. Principles of marketing research. Cambridge, MA: Blackwell.

Bailey, T. 1993. Discretionary effort and the organization of work: Employee participation and work reform since Hawthorne (Working paper). New York: Columbia University.

Barney, J. B. 1991. Firm resources and sustained competitive advantage. Journal of Management, 17: 99-120.

Baron, R., \& Kenny, D. 1986. The moderator-mediating variable distinction in social-psychological research. Journal of Personality and Social Psychology, 51: 1173-1182. 
Batt, R. 2002. Managing customer services: Human resource practices, quit rates, and sales growth. Academy of Management Journal, 45: 587-597.

Becker, B., \& Gerhart, B. 1996. The impact of human resource management on organizational performance: progress and prospects. Academy of Management Journal, 39: 779-801.

Becker, B. E., \& Huselid, M. A. 1998. High performance work systems and firm performance: A synthesis of research and managerial implications. In G. R. Ferris, (Ed.), Research in personnel and human resources: 53101. Greenwich, CT: JAI.

Becker, B. E., \& Huselid, M. A. 2006. Strategic human resources management: Where do we go from here? Journal of Management, 32: 898-925.

Bentler, P. M. 1995. EQS structural equations program manual. Encino, CA: Multivariate Software Inc.

Bhattacharya, M., Gibson, D. E., \& Doty, D. H. 2005. The effects of flexibility in employee skills, employee behaviors, and HR practices on firm performance. Journal of Management, 31: 622-640.

Boles, J. S., Brashear, T., Bellenger, D., \& Barksdale, H. 2000. Relationship selling behaviours: Antecedents and relationships with performance. Journal of Business and Industrial Marketing, 15: 141-153.

Borucki, C. C., \& Burke, M. J. 1999. An examination of service-related antecedents to retail store performance. Journal of Organizational Behavior, 20: 943-962.

Boxall, P. 1999. Human resource strategy and industry-based competition: A conceptual framework and agenda for theoretical development. In P. Wright, L. Dyer, J. Boudreau, \& G. Milkovich (Eds.), Research in personnel and human resources management: Suppl. 4, 259-281. Greenwich, CT: JAI.

Boxall, P., \& Purcell, J. 2000. Strategic human resource management: Where have we come from and where should we be going? International Journal of Management Reviews, 2: 183-203.

Camelo, C., Martín, F., Romero, P. M., \& Valle, R. 2004. Human resources management in Spain: Is it possible to speak of a typical model? International Journal of Human Resource Management, 15: 935-958.

Campbell, D. J. 2000. The proactive employee: Managing workplace initiative. Academy of Management Executive, 14(3): 52-66.

Campbell, D. J., Campbell, C. M., \& Chia, H. 1998. Merit pay, performance appraisal, and individual motivation: An analysis and alternative. Human Resource Management, 37: 131-146.

Cappelli, P., \& Newmark, D. 2001. Do "high-performance" work practices improve establishment-level outcomes? Industrial and Labor Relations Review, 54: 737-775.

Cappelli, P., \& Newmark, D. 2004. External churning and internal flexibility: Evidence on the functional flexibility and core-periphery hypotheses. Industrial Relations, 43: 148-182.

Cavanaugh, M. A., \& Noe, R. A. 1999. Antecedents and consequences of relational components of the new psychological contract. Journal of Organizational Behavior, 20: 323-340.

Chadwick, C., \& Cappelli, P. 1999. Alternatives to generic strategy typologies in strategic human resource management. In P. Wright, L. Dyer, J. Boudreau, \& G. Milkovich (Eds.), Research in personnel and human resources management: Suppl. 4, 1-29. Greenwich, CT: JAI.

Challis, D., Samson, D., \& Lawson, B. 2005. Impact of technological, organizational and human resource investments on employee and manufacturing performance: Australian and New Zealand evidence. International Journal of Production Research, 43: 81-107.

Chonko, L. B., Jones, E., Roberts, J. A., \& Dubinsky, A. J. 2002. The role of environmental turbulence, readiness for change, and salesperson learning in the success of sales force change. Journal of Personal Selling and Sales Management, 22: 227-245.

Cobb, A. T., Folger, R., \& Wooten, K. 1995. The role justice plays in organizational change. Public Administration Quarterly, 19: 135-151.

Colbert, B. A. 2004. The complex resource-based view: Implications for theory and practice in strategic human resource management. Academy of Management Review, 29: 341-358.

Cordery, J. 1989. "Multi-skilling": A discussion of proposed benefits of new approaches to labour flexibility within enterprises. Personnel Review, 18(3): 13-22.

Cordery, J., Sevastos, P., Mueller, W., \& Parker, S. 1993. Correlates of employee attitudes toward functional flexibility. Human Relations, 46: 705-723.

Crant, J. M. 1995. The proactive personality scale and objective job performance among real estate agents. Journal of Applied Psychology, 80: 532-537. 
Delaney, J. T., \& Huselid, M. A. 1996. The impact of human resource management practices on perceptions of organizational performance. Academy of Management Journal, 39: 949-969.

Delery, E. J., \& Doty, D. H. 1996. Modes of theorizing in strategic human resource management: Tests of universalistic, contingency, and configurational performance predictions. Academy of Management Journal, 39: 802-835.

Delery, J. E. 1998. Issues of fit in strategic human resource management: Implications for research. Human Resource Management Review, 8: 289-309.

De Menezes, L. M., \& Wood, S. 2006. The reality of flexible work systems in Britain. International Journal of Human Resource Management, 17: 1-33.

De Saá, P., \& García, F. J. 2001. El sistema de recursos humanos y el desarrollo de capacidades organizativas: Una aplicación empírica en el sector de las cajas de ahorro españolas [Human resource systems and the development of organizational capabilities: An empirical research in the Spanish financial sector]. Cuadernos de Economía y Dirección de la Empresa, 8(Enero/abril): 109-136.

Dorenbosch, L., van Veldhoven, M., \& Poell, R. 2005, January. All for one or one for all? Two distinct concepts of internal consistency among human resource management practices. Paper presented at the PromovendiCongress, University of Tilburg, the Netherlands.

Dyer, L., \& Ericksen, J. 2005. In pursuit of marketplace agility: Applying precepts of self-organizing systems to optimize human resource scalability. Human Resource Management, 44: 183-188.

Dyer, L., \& Reeves, T. 1995. HR strategies and firm performance: What do we know and where do we need to go? International Journal of Human Resource Management, 6: 656-670.

Dyer, L., \& Shafer, R. A. 1999. From human resource strategy to organizational effectiveness: Lessons from research on organizational agility. In P. Wright, L. Dyer, J. Boudreau, \& G. Milkovich (Eds.), Research in personnel and human resources management: Suppl. 4, 145-174. Greenwich, CT: JAI.

Dyer, L., \& Shafer, R.A. 2002. Dynamic organizations: Achieving marketplace and organizational agility with people. In R. Peterson \& E. Mannix (Eds.), Understanding the dynamic organization. Mahwah, NJ: Lawrence Erlbaum.

Edwards, P., \& Wright, M. 2001. High-involvement work systems and performance outcomes: The strength of variable, contingent and context-bound relationships. International Journal of Human Resource Management, 12: 568-585.

Evans, P., \& Genadry, N. 1999. A duality-based prospective for strategic human resource management. In G. R. Ferris (Ed.), Research in personnel and human resources: Suppl. 4, 367-395. Greenwich, CT: JAI.

Farrell, S., \& Hakstian, A. R. 2001. Improving salesforce performance: A meta-analytic investigation of the effectiveness and utility of personnel selection procedures and training interventions. Psychology and Marketing, 18: 281-316.

Fey, C. F., Bjorkman, I., \& Pavlovskaya, A. 2000. The effect of human resource management practices on firm performance in Russia. International Journal of Human Resource Management, 11: 1-18.

Flaherty, T. B., Dahlstrom, R., \& Skinner, S. J. 1999. Organisational values and role stress as determinants of customer-oriented selling performance. Journal of Personal Selling and Sales Management, 28: 1-19.

Fornell, C., \& Larcker, D. F. 1981. Evaluating structural equations models with unobservable variables and measurement error. Journal of Marketing Research, 18: 39-50.

Frenkel, S. J., Korczynski, M., Shire, K. A., \& Tam, M. 1999. On the front line: Organization of work in the information technology. Ithaca, NY: Cornell University Press.

Frese, M., Kring, W., Soose, A., \& Zempel, J. 1996. Personal initiative at work: Differences between East and West Germany. Academy of Management Journal, 39: 37-63.

Friedrich A., Kabst, R., Weber, W., \& Rodehuth, M. 1998. Functional flexibility: Merely reacting or acting strategically. Employee Relations, 20: 504-523.

Gallie, D., Felstead, A., \& Green, F. 2001. Employer policies and organizational commitment in Britain, $1992-97$. Journal of Management Studies, 38: 1081-1101.

Gerhart, B., Wright, P. M., McMahan, G. C., \& Snell, S. A. 2000. Measurement error in research on human resources and firm performance: How much error is there and how does it influence effect size estimates? Personnel Psychology, 53: 803-834.

Guest, D. 1987. Human resource management and industrial relations. Journal of Management Studies, 24: $503-$ 521. 
Guest, D. E. 1997. Human resource management and performance: A review and research agenda. International Journal of Human Resource Management, 8: 263-276.

Guest, D. E., \& Conway, N. 2002. Communicating the psychological contract: an employer perspective. Human Resource Management Journal, 12(2): 22-38.

Guthrie, J. P. 2001. High-involvement work practices, turnover, and productivity: Evidence from New Zealand. Academy of Management Journal, 44: 180-190.

Hesketh, B., \& Neal, A. 1999. Technology and performance. In D. Ilgen \& E. Pulakos (Eds.), The changing nature of performance. Implications for staffing, motivation, and development: 21-55. San Francisco: Jossey-Bass.

Hitt, M. A., Keats, B. W., \& Demarie, S. M. 1998. Navigating in the new competitive landscape: Building strategic flexibility and competitive advantage in the 21st century. Academy of Management Executive, 12(4): 22-42.

Holmbeck, G. M. 1997. Toward terminological, conceptual, and statistical clarity in the study of mediatings and moderators: Examples from the child-clinical and pediatric psychology literatures. Journal of Consulting and Clinical Psychology, 65: 699-710.

Huselid, M. A. 1995. The impact of human resource management practices on turnover, productivity, and corporate financial performance. Academy of Management Journal, 38: 635-672.

Huselid, M. A., \& Becker, B. E. 2000. Comment on measurement error in research on human resources and firm performance: How much error is there and how does it influence effect size estimates? Personnel Psychology, 53: $835-854$.

Huselid, M. A., Jackson, S. E., \& Schuler, R. S. 1997. Technical and strategic human resource management effectiveness as determinants of firm performance. Academy of Management Journal, 40: 171-188.

Ichniowski, C. 1990. Human resource management systems and the performance of U.S. manufacturing businesses (Working Paper No. 3449). Washington, DC: National Bureau of Economic Research.

Ichniowski, C., Shaw, K., \& Prennushi, G. 1997. The effects of human resource management practices on productivity: A study of steel finishing lines. American Economic Review, 87: 291-313.

Ilgen, D. R., \& Pulakos, E. D. 1999. Introduction: Employee performance in today's organisations. In D. Ilgen \& E. Pulakos (Eds.), The changing nature of performance. implications for staffing, motivation, and development: 21-55. San Francisco: Jossey-Bass.

Ingram, T. N. 2004. Future themes in sales and sales management: Complexity, collaboration, and accountability. Journal of Marketing Theory and Practice, 12(4): 18-28.

Kalleberg, A. L. 2001. Organizing flexibility: The flexible firm in a new century. British Journal of Industrial Relations, 39: 479-504.

Kara, S., Kayis, B., \& O'Kane, S. 2002. The role of human factors in flexibility management: A survey. Human Factors and Ergonomics in Manufacturing, 12: 75-119.

Karuppan, C. M. 2004. Strategies to foster labor flexibility. International Journal of Productivity and Performance Management, 53: 532-547.

Katou, A. A., \& Budhwar, P. W. 2006. Human resource management systems and organizational performance: A test of a mediating model in the Greek manufacturing context. International Journal of Human Resource Management, 17: 1223-1253.

Kelliher, C., \& Riley, M. 2003. Beyond efficiency: Some by-products of functional flexibility. Service Industries Journal, 23: 98-113.

Kirkman, B. L., \& Rosen, B. 1999. Beyond self-management: Antecedents and consequences of team empowerment. Academy of Management Journal, 42: 58-74.

Koch, M. J., \& McGrath, R. G. 1996. Improving labor productivity: Human resource management policies do matter. Strategic Management Journal, 17: 335-354.

Kuster, B. I., \& Canales, R. P. 2006. Evaluación y control de la fuerza de ventas: Análisis exploratorio [Salespeople appraisal and control systems: An exploratory analysis]. Universia Business Review, 1(9): 42-57.

Lado, A. A., \& Wilson, M. C. 1994. Human resource systems and sustained competitive advantage: A competencybased perspective. Academy of Management Review, 19: 699-727.

Lam, S. S. K., Schaubroeck, J., \& Aryee, S. 2002. Relationships between organizational justice and employee work outcomes: A cross-national study. Journal of Organizational Behavior, 23: 1-18.

Lawler, E. E., III. 1994. From job-based to competency-based organizations. Journal of Organizational Behavior, 15(3): 3-15. 
Lepak, D. P., \& Snell, S. A. 2002. Examining the human resource architecture: The relationships among human capital, employment, and human resource configurations. Journal of Management, 28: 517-543.

Lepak, D. P., Takeuchi, R., \& Snell, S. A. 2003. Employment flexibility and firm performance: Examining the interaction effects of employment mode, environmental dynamism, and technological intensity. Journal of Management, 29: 681-703.

Liao, H., \& Chuang, A. 2004. A multilevel investigation of factors influencing employee service performance and customer outcomes. Academy of Management Journal, 47: 41-58.

MacDuffie, J. 1995. Human resource bundles and manufacturing performance: Organizational logic and flexible production systems in the world auto industry. Industrial and Labor Relations Review, 48: 197-221.

MacDuffie, J. P., \& Kochan, T. A. 1995. Do U.S. firms invest less in human resources? Training in the world auto industry. Industrial Relations, 34: 147-168.

MacKenzie, S. B., Podsakoff, P. M., \& Ahearne, M. 1998. Some possible antecedents and consequences of in-role and extra-role salesperson performance. Journal of Marketing, 62: 87-98.

Marshall, G. W., Moncrief, W. C., \& Lassk, F. 1999. The current state of sales force activities. Industrial Marketing Management, 28: 87-98.

Maurer, T. J., Wrenn, K. A., Pierce, H. R., Tross, S. A., \& Collins, W. C. 2003. Beliefs about "improvability" of career-relevant skills: Relevance to job/task analysis, competency modelling, and learning orientation. Journal of Organizational Behavior, 24: 107-131.

McIlroy, R., Marginson, P., \& Regalia, I. 2004. Regulating external and internal forms of flexibility at local level: Five European regions compared. International Journal of Human Resource Management, 15: 295-313.

Michie, J., \& Sheehan, M. 2001. Labour market flexibility, human resource management and corporate performance. British Journal of Management, 12: 287-306.

Michie, J., \& Sheehan, M. 2005. Business strategy, human resources, labour market flexibility and competitive advantage. International Journal of Human Resource Management, 16: 445-464.

Molleman, E., \& Slomp, J. 1999. Functional flexibility and team performance. International Journal of Production Research, 37: 1837-1858.

Moorman, R. H. 1991. Relationships between organizational justice and organizational citizenship behaviors: Do fairness perceptions influence employee citizenship? Journal of Applied Psychology, 76: 845-855.

Morris, T. 1993. Performance-related pay. London: London Business School Working Papers.

Moynihan, L. M., Gardner, T. M., Park, H. J., \& Wright, P. M. 2001. HR practices and customer satisfaction: The mediating link of commitment (Working Paper No. 01-14). Ithaca, NY: Center for Advanced Human Resource Studies (CAHRS), Cornell University.

Murphy, K. R. 1999. The challenge of staffing a postindustrial workplace. In A. Howard (Ed.), The changing nature of work: 295-324. San Francisco: Jossey-Bass.

Noe, R. A. 1996. Is career management related to employee development and performance? Journal of Organizational Behavior, 17: 119-133.

Ordiz, F. M. 2004. Análisis de la efectividad de las prácticas de recursos humanos en la empresa española [An analysis of the HR practices effectiveness in Spanish companies]. Revista Europea de Dirección y Economía de la Empresa, 13(4): 73-86.

Ostroff, C., \& Bowen, D. E. 2000. Moving human resource to a higher level. Human resource practices and organizational effectiveness. In K. Klein \& S. W. Kozlowski (Eds.), Multilevel theory, research, and methods in organizations: 211-266. San Francisco: Jossey-Bass.

Paré, G., \& Tremblay, M. 2007. The influence of high-involvement human resources practices, procedural justice, organizational commitment, and citizenship behaviors on information technology professionals' turnover intentions. Group \& Organization Management, 32: 326-357.

Park, H. J., Mitsuhashi, H., Fey, C. F., \& Bjorkman, I. 2003. The effect of human resource management practices on Japanese MNC subsidiary performance: A partial mediating role. International Journal of Human Resource Management, 14: 1391-1406.

Parker, S. 2000. From passive to proactive motivation: The importance of flexible role orientations and role breath self-efficacy. Applied Psychology: An International Review, 49: 447-469.

Parker, S. K., \& Axtell, C. 2000. Seeing another viewpoint: Antecedents and consequences of employee perspective taking. Academy of Management Journal, 44: 1085-1100. 
Paterson, J. M., Green, A., \& Cary, J. 2002. The measurement of organizational justice in organizational change programmes: A reliability, validity and context-sensitivity assessment. Journal of Occupational and Organizational Psychology, 75: 393-408.

Paul, A. K., \& Anantharaman, R. N. 2003. Impact of people management practices on organizational performance: analysis of a causal model. International Journal of Human Resource Management, 14: 1246-1266.

Peña, G.-P. I., \& Hernández, P. F. 2006. Análisis de la estrategia de negocio y de la integración de la función de personal en el proceso estratégico como moderadoras de la efectividad de los sistemas ideales de recursos humanos [Analysis of the competitive strategy and strategic integration of the HR function as moderator of the efficacy of the hr systems]. Revista de Economía y Empresa, 36(24): 13-29.

Penrose, E. T. 1959. The theory of growth of the firm. Oxford, UK: Basil Blackwell.

Podsakoff, P. M., MacKenzie, S. B., Lee, J. Y., \& Podsakoff, N. P. 2003. Common method biases in behavioural research: A critical review of the literature and recommended remedies. Journal of Applied Psychology, 88: 879-903.

Podsakoff, P. M., \& Organ, D. W. 1986. Self-reports in organizational research: Problems and prospects. Journal of Management, 12: 69-82.

Pulakos, E. D., Arad, S., Donovan, M. A., \& Plondon, K. E. 2000. Adaptability in the workplace: Development of a taxonomy of adaptive performance. Journal of Applied Psychology, 85: 612-624.

Ramsay, H., Scholarios, D., \& Harley, B. 2000. Employees and high-performance work systems: Testing inside the black box. British Journal of Industrial Relations, 38: 501-531.

Riley, M., \& Lockwood, A. 1997. Strategies and measurement for workforce flexibility: An application of functional flexibility in a service setting. International Journal of Operations and Production Management, 17: 413-419.

Rodríguez, P. J. M. 2003. Influencia de los sistemas de gestión de recursos humanos sobre los resultados organizativos percibidos: un análisis de la industria manufacturera española [Influence of HR systems on perceived organizational performance: Analysis of the Spanish manufacturing industry]. Investigaciones Europeas de Dirección y Economía de la Empresa, 9(1): 31-48.

Román, S., Ruiz, S., \& Munuera, J. L. 2002. The effects of sales training on sales force activity. European Journal of Marketing, 36: 1341-1366.

Rönnmar, M. 2004. The managerial prerogative and the employee's duty to work: A comparative study of functional flexibility in working life. International Journal of Human Resource Management, 15: 451-458.

Sanchez, R. 1997. Preparing for an uncertain future. Managing organizations for strategic flexibility. International Studies of Management and Organizations, 27: 71-94.

Sanchez, R. 2004. Understanding competence-based management. Identifying and managing five modes of competence. Journal of Business Research, 57: 518-532.

Seibert, S. E., Crant, J. M., \& Kraimer, M. L. 1999. Proactive personality and career success. Journal of Applied Psychology, 84: 416-427.

Senge, P. M. 1990. The fifth discipline: the art and practice of the learning organization. New York: Doubleday.

Senge, P. M. 1993. Transforming the practice of management. Human Resource Development Quarterly, 4: 5-32.

Shafer, R. A., Dyer, L., Kitty, J., Amos, J., \& Ericksen, G. A. 2001. Crafting a human resource strategy to foster organizational agility: A case study. Human Resource Management, 40: 197-211.

Short, J., Ketchen, D., \& Palmer, T. 2002. The role of sampling in strategic management research on performance: A two-study analysis. Journal of Management, 28: 363-385.

Simon, H. A. 1993. Altruism and economics. American Economic Review, 83: 156-161.

Slater, S. F., \& Olson, E. M. 2000. Strategy type and performance: The influence of sales force management. Strategic Management Journal, 21: 813-829.

Snell, S. A., \& Dean, J. W. 1992. Integrated manufacturing and human resource management: A human capital perspective. Academy of Management Journal, 35: 467-504.

Sparrow, P. 1998. The pursuit of multiple and parallel organizational flexibilities: Reconstituting jobs. European Journal of Work and Organizational Psychology, 7(1): 79-95.

Sun, L. Y., Aryee, S., \& Law, K. S. 2007. High-performance human resource practices, citizenship behaviour, and organizational performance: A relational perspective. Academy of Management Journal, 50: 558-577.

Takeuchi, R., Marinova, S. V., Lepack, D. P., \& Moon, H. K. 2004, August. Justice climate as a missing link for the relationship between high investment HRM systems and OCBS. Paper presented at the Academy of Management Conference, New Orleans, LA. 
Tsui, A. S., Pearce, J. L., Porter, L. W., \& Tripoli, A. M. 1997. Alternative approaches to the employee-organization relationship: Does investment in employees pay off? Academy of Management Journal, 40: 1089-1121.

Tüselmann, H. 1996. Progress towards greater labour flexibility in Germany. The impact of recent reforms. Employee Relations, 18: 50-67.

Unsworth, K. L., \& Parker, S. K. 2003. Proactivity and innovation: Promoting a new workforce for the new workplace. In D. Holman, T. D. Wall, C. W. Clegg, P. Sparrow, \& A. Howard (Eds.), The new workplace. A guide to the human impact of modern working practices: 175-196. New York: John Wiley.

Valle, R., Martín, F., Romero, P. M., \& Dolan, S. L. 2000. Business strategy, work processes and human resource training: Are they congruent? Journal of Organizational Behavior, 21: 283-297.

Valverde, M., Tregaskis, O., \& Brewster, C. 2000. Labor flexibility and firm performance. International Advances in Economic Research, 6: 649-661.

van Dam, K., \& Thierry, H. 2000. Employee mobility in perspective: An overview of employee mobility research. Gedrag \& Organisatie, 13: 29-49.

van den Berg, P. T., \& van der Velde, M. E. G. 2005. Relationships of functional flexibility with individual and work factors. Journal of Business and Psychology, 20: 111-129.

Vandenberg, R. J., Richardson, M. A., \& Eastman, L. J. 1999. The impact of high involvement work processes on organizational effectiveness. Group and Organization Management, 24: 300-339.

van den Beukel, A. L., \& Molleman, E. 1998. Multifunctionality: Driving and constraining forces. Human Factors and Ergonomics in Manufacturing, 8: 303-321.

Venkatraman, N. 1989. The concept of fit in strategy research: Toward verbal and statistical correspondence. Academy of Management Review, 14: 423-444.

Verano, T. D., Melián, G. S., \& García, F. J. M. 2006. La retribución y el rendimiento empresarial y del equipo de ventas: un modelo basado en la teoría de los costes de transacción [Rewards and performance of the sales force and the organization: A transaction cost approach]. Investigaciones Europeas de dirección y Economía de la Empresa, 12(2): 35-54.

Verdú, A. J. 2002. Relación entre flexibilidad y desempeño organizativo. Una aproximación desde la perspectiva de la gestión de la calidad total [Relationships between flexibility and organizational performance: An analysis from the TQM perspective]. Elche (Alicante): Ed. Universidad Miguel Hernández.

Volverda, H. W. 1998. Building the flexible firm. How to remain competitive. New York: Oxford University Press.

Walton, R. E. 1985. From control to commitment in the workplace. Harvard Business Review, 63(2): 77-84.

Weitz, B. A., \& Bradford, K. D. 1999. Personal selling and sales management: A relationship marketing perspective. Journal of the Academy of Marketing Science, 27: 241-254.

Wernerfelt, B. 1984. A resource-based view of the firm. Strategic Management Journal, 5: 171-180.

Whitener, E. M. 2001. Do "high commitment" human resource practices affect employee commitment? A crosslevel analysis using hierarchical linear modelling. Journal of Management, 27: 515-535.

Williams, S., Pitre, R., \& Zainuba, M. 2002. Justice and organizational citizenship behavior intentions: Fair rewards versus fair treatment. Journal of Social Psychology, 142: 33-44.

Wilson, D. T. 2000. Deep relationships: The case of the vanishing salesperson. Journal of Personal Selling and Sales Management, 20: 53-61.

Wood, S. 1996. High commitment management and payment systems. Journal of Management Studies, 33: 53-77.

Wood, S., \& Albanese, M. T. 1995. Can we speak of a high commitment management on the shop floor? Journal of Management Studies, 32: 215-247.

Wotruba, T. R. 1996. The transformation of industrial selling: Causes and consequences. Industrial Marketing Management, 25: 327-338.

Wright, P. M. 2003. Next generation SHRM research: From covariation to causation (Working Paper No. 03-01). Ithaca, NY: Center for Advanced Human Resource Studies (CAHRS), Cornell University.

Wright, P. M., \& Gardner, T. 2003. Theoretical and empirical challenges in studying the HR practice-firm performance relationship. In D. Holman, T. D Wall, C. W. Clegg, P. Sparrow, \& A. Howard (Eds.), The new workplace. A guide to the human impact of modern working practices: 311-328. New York: John Wiley.

Wright, P. M., Gardner, T. M., \& Moynihan, L. M. 2003. The impact of HR practices on the performance of business units. Human Resource Management Journal, 13: 21-36.

Wright, P. M., McCormick, B., Sherman, W. S., \& McMahan, G. C. 1999. The role of human resource practices in petro-chemical refinery performance. International Journal of Human Resource Management, 10: 551-571. 
Wright, P. M., McMahan, G. C., \& McWilliams, A. 1994. Human resources and sustained competitive advantage: A resource-based perspective. International Journal of Human Resource Management, 5: 301-326.

Wright, P. M., Smart, D. L., \& McMahan, G. C. 1995. Matches between human resources and strategy among NCAA basketball teams. Academy of Management Journal, 38: 1052-1074.

Wright, P. M., \& Snell, S. A. 1998. Toward a unifying framework for exploring fit and flexibility in strategic human resource management. Academy of Management Review, 23: 756-772.

Youndt, M. A., \& Snell, S. A. 2004. Human resource configurations, intellectual capital, and organizational performance. Journal of Managerial Issues, 16: 337-360.

Youndt, M. A., Snell, S. A., Dean, J. W., \& Lepak, D. P. 1996. Human resource management, manufacturing strategy, and firm performance. Academy of Management Journal, 39: 836-866.

\section{Biographical Notes}

Inmaculada Beltrán-Martín is an assistant professor at the Department of Business Management and Marketing at Universitat Jaume I (Castellón, Spain). She obtained her PhD in business administration. Her current research interests include labor flexibility and strategic human resource management.

Vicente Roca-Puig earned his PhD degree at the University Jaume I. He is an associate professor at the Department of Business Administration and Marketing at the Universitat Jaume I (Castellón, Spain). He is currently working on high-commitment management and contingent workers in small firms and its interrelationship to various organizational strategies.

Ana Belén Escrig-Tena earned her PhD in business management. She is an associate professor at the Department of Business Administration and Marketing at the Universitat Jaume I (Castellón, Spain). Her primary research interests cover flexibility, human resource management, and quality management.

Juan Carlos Bou-Llusar $(\mathrm{PhD})$ is an associate professor at the Department of Business Administration and Marketing at the Universitat Jaume I (Castellón, Spain). His primary research interests cover total quality management and business strategy. Another of his main interests relates to methodological issues involved in the construction of social science measurement instruments. 